NBER WORKING PAPER SERIES

\title{
THE EFFECT OF JOB SECURITY REGULATIONS \\ ON LABOR MARKET FLEXIBILITY: EVIDENCE FROM THE COLOMBIAN LABOR MARKET REFORM
}

\author{
Adriana D. Kugler \\ Working Paper 10215 \\ http://www.nber.org/papers/w10215
NATIONAL BUREAU OF ECONOMIC RESEARCH
1050 Massachusetts Avenue
Cambridge, MA 02138
January 2004

I am grateful to George Akerlof, Josh Angrist, Giuseppe Bertola, Antonio Cabrales, Hugo Hopenhayn, Bernardo Kugler, David Levine, Ricardo Paes de Barros and especially Dan Hamermesh, James Heckman, and Carmen Pagés for very helpful comments. I also thank the Inter-American Development Bank for financial support and seminar participants at the various meetings of the Research Network Study on Labor Market Regulation for comments. Jairo Augusto Nuñez provided the National Household Surveys. The views expressed herein are those of the authors and not necessarily those of the National Bureau of Economic Research.

C2003 by Adriana D. Kugler. All rights reserved. Short sections of text, not to exceed two paragraphs, may be quoted without explicit permission provided that full credit, including (C) notice, is given to the source. 
The Effect of Job Security Regulations on Labor Market Flexibility:

Evidence from the Colombian Labor Market Reform

Adriana D. Kugler

NBER Working Paper No. 10215

January 2004

JEL No. J41, J63, J64, J65, J68

\begin{abstract}
Job security provisions are widely believed to reduce dismissals and hiring. In addition, in developing countries job security is believed to reduce compliance with labor regulations and to increase informal activity. Reductions in dismissal costs are, thus, often advocated as a way to increase labor market flexibility and to increase compliance with labor regulations. This paper analyzes the impact of a substantial reduction in dismissal costs introduced by the Colombian Labor Market Reform of 1990. A theoretical model illustrates the effect of dismissal costs when there is a noncompliant sector. The model shows the direct effect of a reduction in dismissal costs on increased turnover as well as the second order effects on wages and on the composition of the compliant and noncompliant sectors. Using microdata from the Colombian National Household Surveys, I exploit the temporal variability in dismissal costs together with the variability in coverage between formal and informal workers (who are not covered and were, thus, not directly affected by the reform). The differences-in-differences results indicate increased separations and accessions for formal workers relative to informal workers after the reform. Moreover, the increase in worker turnover was greatest among younger workers, more educated workers, and workers employed in larger firms who are most likely to have been affected by the reform. The estimates, together with the steady-state conditions of the model, suggest the reform contributed to $10 \%$ of the reduction in unemployment during the period of study.
\end{abstract}

Adriana Kugler

University of Houston

Department of Economics

209C McElhinney Hall

Houston, TX 77204-5882 and

Department of Economics

Universitat Pompeu Fabra

Ramon Trias Fargas, 25-27

08005 Barcelona

Spain

adkugler@uh.edu 


\section{Introduction}

Job security regulations are usually considered to inhibit labor market flexibility by reducing the ability of firms to hire and fire workers. While severance pay and other job security provisions admittedly protect workers from unjust termination, these laws may also adversely affect workers by reducing their ability to find new jobs. State-mandated severance pay and job security requirements are equivalent to taxes on job destruction that reduce firms' incentives not only to dismiss but also to hire new workers. In fact, it has often been suggested that the elevated severance pay and job security requirements in Europe are in part to blame for the high unemployment levels in this continent.

The perception that reducing firing costs would help to reduce unemployment by enhancing labor market flexibility, through increased worker turnover into and out of unemployment, has driven several European countries to introduce labor market reforms in this direction. In particular, a number of countries including, England, France, Germany, and Spain, introduced temporary contracts during the 1980 's as a way of reducing severance payments and payments for unjust dismissals. In contrast, American labor markets became more rigid during the 1980's. During this decade, a number of states in the U.S. introduced indemnities for unjust dismissals, thus, creating exceptions to the employment-at-will doctrine.

Although the evidence on the effects of these legislative changes on employment and unemployment in Europe and the U.S. has been ambiguous, reforms to reduce labor market rigidities have also been advocated and implemented in a number of less developed countries. In less developed countries the effects of these reforms are considered to be even greater, as labor market regulations are considered not only to discourage hiring and firing, but in addition to encourage noncompliance with labor legislation and the expansion of the informal sector. 
In this paper, I consider the incidence of a substantial reduction of firing costs on flexibility and unemployment in a less developed country. In particular, this paper studies the impact of the Colombian labor market reform of 1990, which reduced severance payments substantially, on worker flows into and out of unemployment and its implied net effect on unemployment. I use a micro-level data set from Colombia to examine the effects of a reduction in firing costs on worker turnover. The labor market reform introduced in Colombia in 1990 reduced severance payments for all workers hired after 1990 and covered by the legislation (formal sector workers). Informal workers, who are not covered by the legislation, were not directly affected by the reform and, thus, are used as a comparison group in the estimations. The empirical analysis exploits this variability in the coverage of the legislation between formal and informal sector workers together with the temporal change in the Colombian legislation to identify the effects of a reduction in firing costs on the exit rates out of employment and out of unemployment. The Colombian Household Surveys for June provide information about formal and informal sector activity and allow estimating hazard rates for formal and informal workers, before and after the reform. The results of the hazard models using a differences-in-differences estimator indicate that hazard rates into and out of unemployment increased after the reform for formal sector workers (covered by the legislation) relative to informal workers (uncovered). Moreover, the increase in worker turnover was greater among younger more educated workers employed in larger firms who are likely to have been affected most by the changes in the legislation.

The rest of the paper proceeds as follows. In Section II, I survey the evidence on the effect of firing costs on employment volatility, the speed of employment adjustment, and employment levels, labor market participation, and unemployment for developed countries. In 
Section III, I describe the legislative changes, introduced by the Colombian labor market reform of 1990 that led to a reduction in severance pay and other firing costs. In section IV, I develop a matching model with endogenous sorting into a formal and an informal sector. The model is useful as it predicts the direct effect of a reduction in severance pay on worker turnover as well as the general equilibrium effects of the reform on turnover in the two sectors. Section V discusses the identification strategy of the firing cost effects on worker turnover. In Section VI, I describe the data and present the results on the incidence of firing costs on the exit rates into and out of unemployment. In Section VII, I use the steady-state condition from the model together with the results in Section VI to estimate the net impact of the reform on unemployment. Section VIII concludes.

\section{Review of the Literature}

The perception that flexible labor markets promote employment and reduce unemployment is widely accepted. Yet, the theoretical and empirical evidence on the net effects of firing costs on employment and unemployment are ambiguous.

Past theoretical work on the effects of firing costs shows that while reductions (increases) in firing costs are expected to increase (reduce) hiring and firing as well as employment volatility, the net effects of reductions in firing costs on employment and unemployment are ambiguous. Theoretically, the net effect of firing costs on employment is very sensitive to the assumptions of the model. The net effect of firing costs on employment depends crucially on whether the entry-exit margin is considered and on the stochastic process assumed to be generating the demand shocks. Hopenhayn and Rogerson (1993) simulate the effect of firing costs in a general equilibrium framework with firm entry and exit and they find that an increase in firing costs reduces employment. On the contrary, Bentolila and Bertola (1990) consider a 
partial equilibrium model with a monopolistic firm and find that employment increases slightly with firing costs, because the firing effect dominates the hiring effect. In addition, Bentolila and Dolado (1994) argue that in an insider-outsider model a-lá Lindbeck and Snower (1988), firing costs may strengthen the position of insiders and increase their employment while reducing the employment of outsiders.

Similarly, past empirical evidence indicates that lower firing costs are related to greater employment volatility, but the evidence of the net effect of firing costs on employment and unemployment in these studies has been mixed. Bertola (1990) constructs job security indices for ten countries and finds that job security provisions are negatively correlated with the variance of employment and with unemployment's response to output changes (i.e., Okun's coefficient). Using a panel of retail firms in the U.S., Anderson (1993) finds that the seasonal variability in employment is lower in firms facing higher adjustment costs. Moreover, a number of studies have related the speed of employment adjustment to shocks to the level of firing costs. As predicted by the theory, Anderson (1993) finds that the probability of responding to shocks is negatively correlated to the adjustment costs faced by firms. In addition, Hamermesh (1993) finds that the speed of employment adjustment to shocks fell in non-unionized industries over the 1980 's in the U.S., when exceptions to the employment-at-will doctrine were being introduced. Using British data Burgess (1993) finds a lower speed of employment in industries subject to higher firing costs. Bentolila and Saint-Paul (1992) also find that employment adjustments over the business cycle increased in Spain after the introduction of temporary contracts in 1984. Thus, these studies provide evidence of the greater employment volatility when firing costs are lower.

The evidence on the impact of firing costs on employment and unemployment, however, 
appear mixed. Lazear (1990) uses cross-country data from 22 developed countries over 29 years and finds evidence suggesting that high severance payments and advance notice requirements reduce employment and labor force participation. Grubb and Wells (1993) construct job security indices for OECD countries and also find a negative correlation between job security and employment. Di Tella and MacCulloch (2004) use a measure of flexibility provided by employers and they find that flexibility is positively correlated with employment and participation, and to a lesser degree with unemployment. In contrast, Bertola (1990) finds evidence suggesting that job security provisions are unrelated to medium and long run employment. Nickell and Layard (1999) find that employment and labor force levels are lower when employment protection legislation (EPL) is stricter, but since they are exploiting crosscountry variation they cannot control for the fact that female labor force participation is lower and EPL stricter in Southern European countries. In fact, they find that the results disappear when considering a sample of adult males. The OECD's Employment Outlook (1999) exploits additional temporal variation in EPL and finds no effect of EPL on aggregate employment. However, consistent with the story that EPL protects insiders, the Employment Outlook finds that EPL increases the employment of adult men and reduces the employment of young workers and women.

Exploiting the temporal change in the labor legislation across states in the U.S., Dertouzos and Karoly (1993) find employment levels fell in states that introduced more stringent employment protection. In contrast, Miles (2000) finds no effect of the changes in unjust dismissal costs in the U.S. on aggregate employment. However, both Autor (2003) and Miles (2000) find that stricter employment protection contributed to the rise in temporary employment in the U.S. over the 1980's. Anderson (1993), instead, exploits the experience-rating feature of 
the U.S. unemployment insurance system to quantify adjustment costs and finds higher average employment in firms subject to higher adjustment costs. The mixed results observed in the literature are not surprising if one considers that cross-section studies are subject to omitted variable biases, simultaneity problems, and endogeneity of the legislation. The panel studies while mitigating the concerns of omitted variable biases and simultaneity are subject to the possibility of endogeneity of the legislation as well as to selection biases. Thus, while the evidence on the effects of firing costs on the volatility of employment appears robust, the net effect of firing costs on employment and unemployment is not as clear. ${ }^{1}$

More recently, a handful of studies have exploited the differential variation in labor legislation for certain groups of workers to set up natural experiments of the impact of firing costs using microdata. While Acemoglu and Angrist (2001) find no effect of the American with Disabilities Act on separations of disabled relative non-disabled, Oyer and Schaefer (2000) find substitution of individual dismissals for mass layoffs after the passage of the Civil Rights Act of 1990 for groups covered by the legislation. Kugler and Saint-Paul (2003) and Autor, Donohue and Schwab (2003) find increased hires and employment in those states that introduced certain unjust dismissal provisions over the 1980's. Finally, Kugler, Jimeno and Hernanz (2003) find increased hiring of young workers and increased separations of older workers after the introduction of the Spanish labor market reform of 1997, which reduced dismissal costs and payroll taxes for these groups of workers.

While micro studies solve some of the problems in studies relying on macrodata, these studies have focused on the impact of firing costs in developed countries. There is little

\footnotetext{
${ }^{1}$ However, a number of recent studies, including Angrist and Kugler (2003), Bertola, Blau and Kahn (2003), and Blanchard and Wolfers (2000), find that the negative effects of labor market institutions on employment and unemployment are realized when economies are faced with bad shocks.
} 
evidence on the impact of firing costs in less developed countries. In the next section, I describe the legislative change introduced in Colombia in 1990, which allows to exploit the temporal variability and the variability in coverage of labor legislation to estimate the impact of firing costs on turnover and unemployment in a less developed country.

\section{Changes in the Colombian Institutional Framework}

In 1990, Colombia introduced a labor market reform that substantially reduced the costs of dismissing workers. The Colombian reform reduced severance payments, widened the definition of 'just' dismissals, extended the use of temporary contracts, and speeded up the process of mass dismissals. All of these policy changes reduced the costs of firing workers covered by the legislation after $1990 .^{2}$ The reform, thus, reduced firing costs for firms in the formal sector but not for informal firms, which did not comply with labor legislation.

Although the reform introduced various legislative changes simultaneously, the one major policy change that decreased the costs of dismissals was the reduction of severance payments. ${ }^{3}$ The reform reduced the severance paid for dismissals in three ways. First, prior to the reform, employers were mandated to pay severance of one month per year worked based on the salary at the time of separation. After the reform, employers were, instead, required to deposit a monthly contribution equivalent to one month of the yearly salary at that moment in time to an individual severance payments savings account ("Fondo de Cesantías"), which would be accessible to workers in the event of separation. Thus, total severance payments were reduced because the monthly payment per year worked was no longer based on the higher salary at the

\footnotetext{
${ }^{2}$ In addition to the Labor Market Reform of 1990, a social security reform was passed in 1994 and implemented in 1995 and $1996 . \quad$ However, since the social security reform increased payroll taxes, the increase in non-wage recurrent costs of this reform implies different effects on turnover than the reduction in dismissal costs of the Labor Market Reform of 1990. Moreover, the study by Gruber (1997) of a similar reform in Chile finds no effects of payroll taxes on employment because recurrent costs are passed onto wages.

${ }^{3}$ Note that both before and after the reform, employers were exempt from the payment of severance in cases when employees were dismissed because of undue care, sabotage, or release of employers' proprietary information.
} 
time of separation, but rather on the salary during each month. Second, prior to the reform, workers could obtain advance payments from their severance to use for investments in education and housing, that would only be credited to the employer in nominal terms in the event of separation. After the reform, although the withdrawal of funds was still permitted, these 'loans' were now credited to the employer in real terms. According to Ocampo (1987), the fact that, prior to the reform, withdrawals were credited to the employer in nominal terms implied, on average, a cost of $35 \%$ of the total severance payments in the manufacturing sector prior to 1990 . Finally, the change in the legislation reduced severance pay, because the introduction of guaranteed severance payments essentially turned severance payments into a deferred compensation scheme, allowing workers lower wages in exchange for future severance. ${ }^{4}$ Not all workers were, however, affected in the same way by the reduction in severance payments. As indicated above, workers hired by informal firms are not covered by the legislation and, thus, should not had been affected directly by the reform. Moreover, family workers, temporary workers, and workers employed by firms with 5 or less employees are not entitled to severance payments, and domestic workers and workers employed by firms with very little capital are entitled only to a severance payment of 15 days per year worked.

A second important change introduced by the reform was the change in the legislation with regards to indemnities for 'unjust' dismissals. First, the definition of 'unjust' dismissals changed in 1990. Prior to the reform, 'just' cause dismissals included dismissals of employees because of fraud, violence, undue care, sabotage, discipline problems, deficient performance, and release of proprietary information. After the reform, the definition of 'just' cause dismissals was extended to include any dismissal for failure to comply with firm regulations and instructions

\footnotetext{
${ }^{4}$ Kugler (2002) studies the impact a change from a standard severance payments system into a system of severance payments savings accounts.
} 
from one's supervisors. The exemptions for the payment of indemnities for 'unjust' dismissals were thus extended after the 1990 reform, reducing firing costs for formal firms. Second, the reform eliminated the ability of workers with more than ten years of tenure to sue for backpay and reinstatement. At the same time, however, the reform increased the cost of 'unjustly' dismissing workers with more than ten years of tenure (see Table 1) and this may have increased the incentives for firms to dismiss workers just before reaching 10 years of seniority. ${ }^{5}$ Thus, these changes in 'unjust' dismissal legislation can be expected to have the greatest impact on formal workers with intermediate levels of seniority.

Another important change brought about by the reform was the extension of the use of fixed-term contracts. ${ }^{6}$ Prior to 1990 , fixed term-contracts were allowed for a minimum duration of a year. ${ }^{7}$ After the reform, these fixed-term contracts were extended to contracts of less than a year (renewable up to three times). This change in the legislation, thus, lowered firing costs for firms hiring workers for less than a year and would be expected to have increased turnover among formal workers with less than a year of tenure after the reform.

An additional change introduced by the reform was a reduction in the advance notice for mass dismissals. While advance notice requirements for mass layoffs existed prior to the reform (see Table 2), the reform introduced penalties to bureaucrats who did not process requests for mass layoffs quickly. If such threats to bureaucrats were effective, this change in the legislation should have speeded up the dismissal process for formal firms and lowered their costs of firing.

Finally, the reform also introduced a new type of contract that eliminated severance

\footnotetext{
${ }^{5}$ Note, however, that employees with more than ten years of experience hired before 1990 could also choose to be covered by the new regime with Severance Payments Savings Accounts.

${ }^{6}$ While temporary contracts are subject to payroll taxes and social security contributions, these contracts are not subject to severance pay and 'unjust' dismissal legislation as long as contracts end by the agreed date.

${ }^{7}$ Despite legislation on fixed-term contracts, however, firms could circumvent this restriction by subcontracting workers from temp agencies even prior to the reform.
} 
payments altogether. This type of contract ("Salario Integral") allowed formal workers who earned more than ten times the minimum wage to opt out of severance payments, indemnities for unjust dismissals, benefits (except paid vacations), social security contributions, and payroll taxes in exchange for a higher salary. The introduction of this type of contract effectively allowed firms to eliminate the cost of dismissing highly paid workers who opted for the "Salario Integral". Thus, one would expect to find a greater effect of the reform on formal sector workers with salaries above ten minimum wages. ${ }^{8}$

The changes in severance pay legislation, 'unjust' dismissal legislation, temporary contracts, and mandatory advance notice introduced by the Colombian Labor Market Reform should have directly reduced the costs of dismissals for formal firms and increased turnover in the formal sector. Moreover, it is often argued that job security regulations simply encourage the expansion of the informal sector and one would, thus, expect for this type of reform to have encouraged greater compliance with the legislation. The next section introduces a matching model with firing costs, which shows the direct effect on formal turnover of a reduction in firing costs as well as the indirect effects on formal and informal turnover through the compositional changes of firms in each sector. The model shows that a reform that reduces dismissal costs may not only increase turnover, but it may also increase compliance with state-mandated firing costs.

\section{A Sorting Model of Compliance with Job Security Provisions}

This section presents a matching model with a formal sector and an informal sector in which firms sort themselves between the two sectors. Firms producing in the formal sector must comply with labor legislation and have to pay state-mandated severance in the event of a

\footnotetext{
${ }^{8}$ By 1994 only $1.5 \%$ of all workers in manufacturing and $0.6 \%$ of workers in commerce had opted for this type of contract (Lora and Henao, 1995). Since the surveys used in the analysis do not indicate whether a worker indeed opted for an Integral Salary, we examine whether the impact of the reform was greater on older and highly educated workers who are more likely to earn above ten minimum wages.
} 
dismissal, while firms in the informal sector do not comply with job security legislation and avoid the severance payment. Productivity in the informal sector is, however, lower overall than in the formal sector because informal firms must produce at a smaller scale to remain inconspicuous to the authorities. Moreover, the presence of a firm-specific component to productivity in the model implies that, in equilibrium, firms with higher idiosyncratic productivity self-sort into the formal sector while firms with lower idiosyncratic productivity self-sort into the informal sector.

The model predicts that the probability of being dismissed by a formal firm is lower because of the legislated severance payments, but also because formal firms are more productive. Also, a reduction in severance payments increases the probability of dismissals in the formal sector through a direct effect on the firing costs. In addition, however, the reduction in firing costs has effects on the idiosyncratic composition of firms in each sector as well as on the wages paid in each sector. This model, thus, highlights the potential biases that may arise in empirical studies that attempt to quantify the effects of firing costs.

\section{A. Assumptions}

In this model, heterogeneous firms may choose to produce in a formal sector in which they must comply with job security provisions or to produce in the informal sector without complying but at the cost of lower productivity. Workers are identical ex-ante, but they may have different productivity ex-post depending on how well they match. After a match, the firm and worker set the wage according to a Nash-bargaining solution. Then, the firm decides whether to keep or dismiss the worker.

\section{Production in Each Sector}

Formal and informal production is a function of a sector-specific component, $\mathrm{a}_{\mathrm{s}}$, of a 
firm-idiosyncratic component, A, and of the match-quality component, $\gamma$, and produce with a technology, $Y_{s}=a_{s} \gamma A$, for $s=F$, I. Sector-specific productivity is fixed and it is assumed, without loss of generality, that $\mathrm{a}_{\mathrm{F}}=1>\mathrm{a}_{\mathrm{I}}=\mathrm{a}$. The firm-idiosyncratic component comes from a distribution $\mathrm{F}(\mathrm{A})$, and the match-quality component comes from a distribution $\mathrm{G}(\gamma)$.

\section{Timing}

Firms, first, observe their firm-specific productivity. Firms then choose a sector given the productivity in the sector and their known firm-specific productivity. Formal and informal firms hire in the same market and, immediately after hiring, they observe the match-specific productivity. Then, firms and workers bargain over wages. At the end of the process firms decide whether to keep or dismiss the worker, and formal firms that do dismiss must provide a severance payment, C. However, workers may still be separated afterwards at arrival rates, $\lambda_{F}$ and $\lambda_{\mathrm{I}}$, due to exogenous reasons, in which case firms do not pay severance.

\section{Matching}

All firms and workers search in the same market. The arrival rate of applicants to formal and informal firms is the same, $\mathrm{q}(\theta)=\mathrm{m}(1 / \theta, 1)$, where $\theta=\mathrm{v} / \mathrm{u}$. The arrival rate of job opportunities is $\theta \mathrm{q}(\theta)$, and workers receive offers from formal or informal firms with a given probability that depends on the share of firms in each sector.

\section{Wage-setting}

Each firm and worker pair sets the wage based on Nash bargaining. Wages are set after firm-specific and match-specific productivities are observed. In this model, all wages are affected by job security legislation, because the severance pay raises the utility of the 
unemployed and thus raises the reservation wage of all workers. ${ }^{9}$

\section{B. Solution to the Model}

The model is solved by backward induction. First, the solution for the dismissal choices in each sector is found. Second, the Nash-bargaining solution of the wage is determined. Finally, the marginal firm between the two sectors is determined to solve for the split of firms between the formal and informal sectors.

\section{Dismissal Decisions}

The present discounted profits for a firm with a filled job is $\mathrm{J}_{\mathrm{s}}$ and the present discounted value of a vacant job is $\mathrm{V}_{\mathrm{s}}$, for $\mathrm{s}=\mathrm{F}$, I (formal and informal, respectively). Thus, the asset equation of a filled and a vacant job are given by the following equations, respectively:

$$
\begin{gathered}
r J_{\mathrm{s}}=\mathrm{Y}_{\mathrm{s}}-\mathrm{w}_{\mathrm{s}}+\lambda_{\mathrm{s}}\left(\mathrm{V}_{\mathrm{s}}-\mathrm{J}_{\mathrm{s}}\right), \\
\mathrm{r} \mathrm{V}_{\mathrm{s}}=\mathrm{q}(\theta)\left(\mathrm{J}_{\mathrm{s}}-\mathrm{V}_{\mathrm{s}}\right),
\end{gathered}
$$

As there is free-entry, and all profit-opportunities are exploited, $\mathrm{V}_{\mathrm{s}}=0$. Thus,

$$
\mathrm{J}_{\mathrm{s}}=\left[\mathrm{a}_{\mathrm{s}} \gamma \mathrm{A}-\mathrm{w}_{\mathrm{s}}\right] /\left(\mathrm{r}+\lambda_{\mathrm{s}}+\mathrm{q}(\theta)\right) .
$$

Once matched, a firm must choose whether to keep or dismiss a worker. A formal firm has to pay a cost, $C$, if it decides to dismiss, while an informal firm does not have to pay the firing cost. Thus, the minimum match-productivity that triggers a dismissal by a formal firm is given by,

$$
\bar{\gamma}_{\mathrm{F}}=\left[\mathrm{w}_{\mathrm{F}}-\mathrm{C}\left(\mathrm{r}+\lambda_{\mathrm{F}}+\mathrm{q}(\theta)\right)\right] / \mathrm{A} .
$$

For informal firms, the trigger productivity is given by,

$$
\bar{\gamma}_{\mathrm{I}}=\left[\mathrm{w}_{\mathrm{I}}\right] / \mathrm{aA}
$$

\footnotetext{
9 As pointed out by Lazear (1990), in a perfectly competitive market, the state-mandated severance pay could be undone given the proper contract. In particular, the worker would have to post a bond for the cost of the severance pay to the firm upon the signing of the contract. However, as in Lazear (1990), it is assumed that the state-mandated severance pay is not completely offset by a private transfer, because workers may be liquidity constrained and because of moral hazard problems on the part of firms.
} 
Given firm-specific productivity and wages, the probability that a formal firm dismisses a worker is less than the probability that an informal firm dismisses, i.e., $\bar{\gamma}_{\mathrm{F}}<\bar{\gamma}_{\mathrm{I}} \Leftrightarrow \mathrm{G}\left(\bar{\gamma}_{\mathrm{F}}\right)<$ $\mathrm{G}\left(\bar{\gamma}_{\mathrm{I}}\right)$. This is both because formal firms must pay severance payments and because sector productivity is higher if producing formally.

\section{Determination of Wages}

Wages are set by each firm-worker pair before the match-quality is realized. Wages are set according to Nash-bargaining, where each side has the same bargaining power. Thus, formal and informal firms split their surplus equally with workers, as follows:

$$
\begin{gathered}
J_{F}^{e}-V_{F}-G\left(\bar{\gamma}_{F}\right) C=E_{F}^{e}-U, \\
J_{I}^{e}-V_{I}=E_{I}^{e}-U,
\end{gathered}
$$

where $\mathrm{J}_{\mathrm{F}}{ }^{\mathrm{e}}, \mathrm{J}_{\mathrm{I}}^{\mathrm{e}}, \mathrm{E}_{\mathrm{F}}{ }^{\mathrm{e}}$, and $\mathrm{E}_{\mathrm{F}}{ }^{\mathrm{e}}$ are the expected discounted profits of a formal and informal job and the expected lifetime utilities of a formal and an informal worker, respectively, and $U$ is the expected lifetime utility of an unemployed worker. The asset equations of employed and unemployed workers are given by,

$$
\begin{gathered}
\mathrm{rE}_{\mathrm{s}}^{\mathrm{e}}=\mathrm{w}_{\mathrm{s}}+\lambda\left(\mathrm{U}-\mathrm{E}_{\mathrm{s}}^{\mathrm{e}}\right), \\
\mathrm{r} \mathrm{U}=\theta \mathrm{q}(\theta)\left(\mathrm{E}^{\mathrm{e}}-\mathrm{U}\right) .
\end{gathered}
$$

Where $\mathrm{E}^{\mathrm{e}}$ is the expected lifetime utility of employment for an unemployed job-seeker. Since an unemployed worker is uncertain about whether he will be hired in a formal or an informal job, his expected utility of employment is:

$$
E^{e}=\operatorname{Pr}(\text { formal offer })\left[\left(1-G\left(\bar{\gamma}_{F}\right)\right) E_{F}^{e}+G\left(\bar{\gamma}_{F}\right) C\right]+\operatorname{Pr}(\text { informal offer })\left(1-G\left(\bar{\gamma}_{I}\right)\right) E_{I}^{e} \text {. }
$$


Solving for $\left(E_{s}^{e}-U\right)$ in each sector and substituting into the equal split equation above determines the wages in each sector:

$$
\begin{gathered}
\mathrm{W}_{\mathrm{F}}=\left\{\left(\mathrm{r}+\lambda_{\mathrm{F}}\right)(\mathrm{r}+\theta \mathrm{q}(\theta))\left[\int \gamma \mathrm{Ag}(\gamma) \mathrm{d} \gamma-\mathrm{G}\left(\bar{\gamma}_{\mathrm{F}}\right) \mathrm{C}\right]+\mathrm{r}\left(\mathrm{r}+\lambda_{\mathrm{F}}+\mathrm{q}(\theta)\right) \theta \mathrm{q}(\theta) \mathrm{E}^{\mathrm{e}}\right\} / \\
\left.\left\{\left(2\left(\mathrm{r}+\lambda_{\mathrm{F}}\right)+\mathrm{q}(\theta)\right)\right)(\mathrm{r}+\theta \mathrm{q}(\theta))\right\}, \\
\mathrm{W}_{\mathrm{I}}=\left\{\left(\mathrm{r}+\lambda_{\mathrm{I}}\right)(\mathrm{r}+\theta \mathrm{q}(\theta))\left[\int \gamma \mathrm{Ag}(\gamma) \mathrm{d} \gamma+\mathrm{r}\left(\mathrm{r}+\lambda_{\mathrm{I}}+\mathrm{q}(\theta)\right) \theta \mathrm{q}(\theta) \mathrm{E}^{\mathrm{e}}\right\} /\right. \\
\left.\left\{\left(2\left(\mathrm{r}+\lambda_{\mathrm{I}}\right)+\mathrm{q}(\theta)\right)\right)(\mathrm{r}+\theta \mathrm{q}(\theta))\right\} .
\end{gathered}
$$

Wages are expected to be higher in the formal sector because of the higher sector-productivity in formal jobs. However, as shown above, in equilibrium the average match-quality is lower in formal sector firms, as firms in this sector are more likely to keep less productive matches than informal firms. Hence, the lower quality of the matches in the formal sector lowers the expected wage in the formal sector. In addition, wages are affected not only by average productivity but also by the level of the firing cost. Both formal and informal wages are raised by the presence of state-mandated severance pay, because the severance payment raises workers' reservation wages.

\section{Sorting into Sectors}

Given dismissal choices and wages, firms choose whether to sort into the formal or the informal sector. The benefit of producing formally is that the productivity of this sector is higher, but the cost of producing in this sector relative to the informal sector is the payment of state-mandated severance in the event of a dismissal. As firms are heterogeneous, firms may split between the two sectors. Firms produce formally if the difference between the expected stream of profits of formal and informal firms is positive, i.e., if $\left[\mathrm{J}_{\mathrm{F}}{ }^{\mathrm{e}}-\mathrm{J}_{\mathrm{I}}^{\mathrm{e}}\right]>0$, and they produce informally if it is negative, i.e., if $\left[\mathrm{J}_{\mathrm{F}}{ }^{\mathrm{e}}-\mathrm{J}_{\mathrm{I}}^{\mathrm{e}}\right]<0$. As the firm-specific productivity increases, the output gains in the formal sector relative to the informal sector increase. Thus, the gains from 
going into the formal sector are greater for more productive firms than for less productive ones:

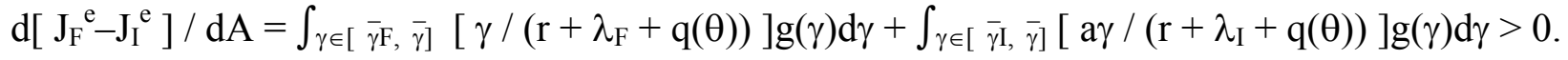

Firms with $A \in\left[\underline{A}, A_{\text {crit }}\right]$ produce in the informal sector, while firms with $A \in\left[A_{\text {crit, }}, \bar{A}\right]$ produce in the formal sector, where $A_{\text {crit }}$ is the firm-specific productivity of the firm that is marginal between producing formally and producing informally. Consequently, since formal firms are more productive in equilibrium, they dismiss less often and they pay higher wages than informal firms. ${ }^{10}$

\section{Severance Pay and Turnover}

The presence of state-mandated costs and higher productivity in the formal sector imply different hazards into and out of unemployment in the two sectors. On the one hand, the probability of endogenous dismissal in the formal sector is likely to be lower than the probability of dismissal in the informal sector, i.e., $\left.\left.\theta \mathrm{q}(\theta)\left(1-\mathrm{F}\left(\mathrm{A}_{\mathrm{m}}\right)\right) \mathrm{G}\left(\bar{\gamma}_{\mathrm{F}}\right)\right)<\theta \mathrm{q}(\theta) \mathrm{F}\left(\mathrm{A}_{\mathrm{m}}\right) \mathrm{G}\left(\bar{\gamma}_{\mathrm{I}}\right)\right)$. On the other hand, the hiring probability will be higher or lower in the formal sector relative to the informal sector depending on the share of firms producing in each sector, i.e., depending on whether $\theta q(\theta)\left(1-F\left(A_{m}\right)\right)>\theta q(\theta) F\left(A_{m}\right)$ or $\theta q(\theta)\left(1-F\left(A_{m}\right)\right)<\theta q(\theta) F\left(A_{m}\right)$. As the proportion of firms producing formally increases, then the hiring probability in the formal sector increases relative to the informal sector.

Moreover, the hazards into and out of unemployment are affected directly and indirectly by changes in severance pay legislation. First, a reduction in state-mandated severance pay has a direct effect on formal firms by increasing the threshold match-productivity that triggers dismissals. Second, a reduction of severance payments pushes down wages in both sectors due

\footnotetext{
${ }^{10}$ The self-sorting of more productive firms into the formal sector, thus, makes evident the problems of identifying the effect of legislation on turnover, simply by estimating the effect of firing cost on the hazard rates.
} 
to the fall in the reservation wage. Wages increase, however, due to the greater probability of dismissal in the formal sector, and the net effect on wages in both sectors is positive as well as the effect of wages on turnover. Finally, a reduction of severance payments changes the composition of firms in each sector. In particular, decreasing severance payments increases the incentives to produce in the formal sector and shifts lower productivity firms, that before were unwilling to produce formally, away from the informal sector. The compositional change increases the dismissal and hiring rates in the formal sector due to the greater share of firms producing formally.

The direct and indirect effects of a reduction in firing costs on turnover that emerge in the model illustrate the problems that may arise when trying to estimate the impact of a change in firing costs on turnover. First, the effects of firing costs on wages imply that the effect of firing costs on turnover captures not only the direct effect mentioned above, but also the indirect effect of firing costs on turnover going through wages. This is not problematic in so far as one is interested in measuring the total effect, both direct and indirect, of firing costs on turnover. However, the self-sorting of firms into formal and informal sectors according to their firmspecific productivity and the effect of the reduction of firing costs on this self-sorting are likely to introduce selection biases. Finally, if a policy change occurred simultaneously with a change in the distribution of the shocks, then one may attribute to the reform an effect that may indeed be due to a worsening in the distribution of the matches. ${ }^{11}$ The next section discusses an identification strategy to deal with the problem of contemporaneous changes in the distribution of the shocks and discusses inference given the presence of a selection problem.

\footnotetext{
${ }^{11}$ In addition, a change in firing costs is also likely to affect turnover in both sectors through its indirect effect on wages.
} 


\section{Identification Strategy}

\section{A. Differences-in-differences}

The theory laid out above suggests that firing costs should only have direct effects on the exit rates of workers in the formal sector (covered by the legislation), but not on the exit rates of workers in the informal sector (uncovered by the legislation). Hence, the firing costs should only have direct effects on the tenures of formal sector workers, but not on the tenures of workers employed in the informal sector. Similarly, the unemployment duration of workers whose spells end as a result of being hired in the formal sector should be directly affected by firing costs, but not those of workers whose spells end as a result of being hired in the informal sector. Comparing the hazards into and out of unemployment (or tenures and unemployment spells) between formal and informal workers (covered and uncovered by the legislation) could then provide an estimate of the effect of firing costs on turnover. The sample counterpart of the firing cost effect on tenure (unemployment spells) using differences would be:

$$
\Delta \overline{\mathrm{s}}=\left[\overline{\mathrm{s}}^{\text {formal }}-\overline{\mathrm{S}}^{\text {informal }}\right],
$$

where, $\overline{\mathrm{h}}$ formal $=1 / \overline{\mathrm{s}}$ formal and $\overline{\mathrm{h}}$ informal $=1 / \overline{\mathrm{s}}$ informal and the $\overline{\mathrm{s}}$ 's are mean tenures (unemployment spells) and the $\overline{\mathrm{h}}$ 's are mean hazard rates. ${ }^{12}$ Considering the simplest possible model of tenure (unemployment duration) with no regressors, tenure (unemployment) depends only on a formal dummy,

$$
\mathrm{s}_{\mathrm{it}}=\beta+\delta \text { Formal }_{\mathrm{it}}+\mathrm{u}_{\mathrm{it}}, \quad \mathrm{E}\left(\mathrm{u}_{\mathrm{it}} \mid \text { Formal }_{\mathrm{it}}\right)=0 .
$$

Given this model, it is easy to see that the difference of the mean tenures in the formal and informal sectors provides an estimate of the firing cost effect, $\delta$. This way of estimating the firing cost effect is, however, likely to be biased for three reasons. First, the two groups may 
have different characteristics and, thus, different turnover behavior and different mean tenures and unemployment spells. Including regressors in the model above allows controlling for observable characteristics and helps to solve this problem. Second, the error term could be correlated with the Formal dummy if there is self-selection into the groups, i.e., $\mathrm{E}\left(\mathrm{u}_{\mathrm{it}} \mid\right.$ Formal $\left._{\mathrm{i}}=1\right)$ $\neq \mathrm{E}\left(\mathrm{u}_{\mathrm{it}} \mid\right.$ Formal $\left._{\mathrm{i}}=0\right)$. Finally, the two groups may be subject to different shocks and part of the differences in turnover patterns and, thus, tenures and unemployment spells, between the groups may be simply capturing these differences, i.e., $\beta_{\mathrm{F}} \neq \beta_{\mathrm{I}}$.

Exploiting the temporal change in the legislation introduced by the labor market reform of 1990, in addition to the variability in coverage between covered and uncovered workers, allows controlling for self-selection and for the difference in shocks across groups. In the model of tenure (unemployment spells) with no regressors, tenure (unemployment) depends only on a formal dummy, on a post-reform dummy, and on an interaction term between the two,

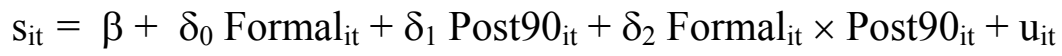

First, if self-selection is constant over time, i.e., $\mathrm{E}\left(\mathrm{u}_{\mathrm{ipre} 90} \mid\right.$ Formal $\left._{\mathrm{i}}=1\right)=$ $\mathrm{E}\left(\mathrm{u}_{\text {ipost90 }} \mid\right.$ Formal $\left._{\mathrm{i}}=1\right)$ and $\mathrm{E}\left(\mathrm{u}_{\text {ipre90 }} \mid\right.$ Formal $\left._{\mathrm{i}}=0\right)=\mathrm{E}\left(\mathrm{u}_{\text {ipost90 }} \mid\right.$ Formal $\left._{\mathrm{i}}=0\right)$, the firing cost effect can be estimated by simply taking differences-in-differences:

$$
\Delta \overline{\mathrm{S}}^{\mathrm{gt}}=\Delta\left[\overline{\mathrm{S}}^{\text {post90}}-\overline{\mathrm{S}}^{\text {pre90}}\right]^{\text {formal }}-\Delta\left[\overline{\mathrm{S}}^{\text {post90 }}-\overline{\mathrm{S}}^{\text {pre90}}\right]^{\text {informal }}
$$

where, $\overline{\mathrm{h}}^{\mathrm{gt}}=1 / \overline{\mathrm{s}}^{\mathrm{gt}}$. Taking differences of average tenures (unemployment duration) for formal workers between the pre-1990 and the post-1990 periods provides an estimate of the firing cost effect and allows to difference out the biases introduced by self-selection when self-selection is constant over time. Taking differences of these differences with respect to informal workers

\footnotetext{
12 This sample counterpart holds as long as the hazards follow a Poisson process.
} 
(uncovered by the legislation) allows controlling for common trends that affect both groups, whether it is a constant trend, $\beta$, or a changing trend common to both groups, $\delta_{1}$.

As indicated above, however, it is possible that the two groups are subject to different shocks, i.e., $\beta_{\mathrm{F}} \neq \beta_{\mathrm{I}}$. In this case, differences-in-differences would work provided that the postreform shocks can be adjusted using pre-reform trends. Thus, differences-in-differences would work even if the trends were different in the two groups under two circumstances. First, differences-in-differences would work if the trends are constant over time for each group, i.e.,

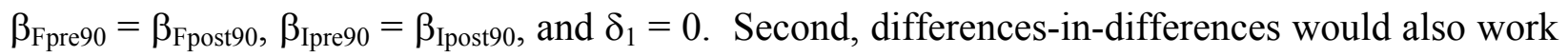
if the trends change over time for each group, but the trends change by a common factor in both groups, i.e., $\beta_{\text {Fpre90 }} \neq \beta_{\text {Fpost90 }}=\beta_{\text {Fpre90 }}+\delta_{1}$ and $\beta_{\text {Ipre90 }} \neq \beta_{\text {Ipost90 }}=\beta_{\text {Ipre90 }}+\delta_{1}{ }^{13}$

To estimate the effect of the reform on the hazard rates into and out of unemployment, the analogue of differences-in-differences is estimated using a formal hazard model. I estimate an exponential model that controls for observables and includes, the formal dummy, the post1990 dummy and the interaction term between the formal and the post-1990 dummy:

$$
\mathrm{h}\left(\mathrm{s}_{\mathrm{it}} \mid \mathbf{X}_{\mathbf{i t}},\right)=\exp \left\{\beta \mathbf{X}_{\mathbf{i t}}+\delta_{0} \text { Formal }_{\text {it }}+\delta_{1} \text { Post90 }_{\text {it }}+\delta_{2} \text { Formal }_{\text {it }} \times \text { Post90 }_{\text {it }}\right\},
$$

where $\mathbf{X}_{\mathbf{i t}}$ is a $1 \times \mathrm{k}$ vector of regressors, and $\beta$ is a $\mathrm{k} \times 1$ vector of parameters. The vector of covariates $\mathbf{X}_{\mathbf{i t}}$, includes: age, education, sex, marital status, number of dependants, the city where the person lives, and industry of employment. The Formal variable is included to control for constant differences between the groups. Thus, $\delta_{0}$ is expected to be negative since the dismissal of formal workers is more costly than that of informal workers, both before and after

\footnotetext{
${ }^{13}$ Moreover, even if trends do not change by a common factor in both groups, an unconventional differences-in-differences estimator could be obtained using a method proposed by Heckman and Robb (1985). This method assumes that a pre-reform model, that is stable over time, could be fit for each group and then used to quantify post-reform shocks that can be inserted into equations fit to post-reform data.
} 
the reform. The Post90 dummy controls for common shocks affecting the turnover behavior of all workers after 1990. Finally, the interaction term of the Formal and Post90 dummies is included to estimate the effect of the reduction in firing costs introduced by the reform on the hazard rates. A test of the impact of the reform is equivalent to a test that the coefficient on the interaction term, $\delta_{2}$, is different from zero. In particular, the test considers whether workers covered by the legislation changed their turnover behavior relative to uncovered workers after 1990.

\section{B. Potential Sources of Contamination}

The identification strategy above exploits both the temporal variability and the crosssection variability available in the Colombian context. Nonetheless, these differences-indifferences estimators rely on a number of assumptions that may yield inconsistent estimates of the effects of firing costs on turnover. First, the differences-in-differences estimators ignore the general equilibrium effects of a reduction in firing costs on composition suggested by the model in the previous section. Second, the estimators rely on the assumption that trends did not change differentially across groups over time. In turn, I consider the implications for the identification of the firing cost effect of having these two potential sources of biases.

As highlighted by the model in the previous section, the reduction of firing costs introduced by the reform is likely to have generated general equilibrium effects. In particular, the model above showed that a reduction in firing costs not only has direct effects on turnover by reducing the costs of dismissals, but it also has indirect effects on turnover through its impact on sector selection. As described above, the differences-in-differences estimator above is consistent as long as self-selection is constant over time. The model in the previous section showed, however, that a reduction in firing costs changes the incentives to sort into the formal and 
informal sectors and generates compositional changes that also affect turnover. Thus, a reduction in firing costs may itself generate compositional changes that invalidate the assumption of a constant self-selection rule, before and after the reform. Yet, the model above does suggest that the bias introduced by differences-in-differences should be negative. In the model, the reduction in firing costs induces firms with low firm-specific productivities to start producing formally and the reallocation between sectors thus lowers the average firm-specific productivity and increases turnover in both sectors. However, the effect of this change in composition on turnover was shown to be greater in the informal sector. Thus, while the firing cost effect obtained with differences-in-differences is inconsistent, the estimate should be a lower bound of the effect of the reduction in firing costs on turnover. Moreover, the next section shows that the change in the size of the two sectors was small and this may indicate that the selection bias is unlikely to be large.

The second reason why the differences-in-differences estimators may yield inconsistent estimates of the firing cost effects is if the trends change differently over time for formal and informal workers. As discussed above, an important assumption that has to be fulfilled for differences-in-differences to yield consistent estimates of the reform is that it eliminates the effect of aggregate shocks or trends on turnover. The effect of aggregate shocks is eliminated if aggregate shocks are common to both groups, or if aggregate shocks are specific to each group but either, the shocks are constant over time or the shocks change similarly across groups. However, if trends are different across groups and they change differently over time, the firing cost effects obtained from differences-in-differences are likely to be biased. Aside from macro shocks, which are common to both groups, there were two additional shocks occurring during this period that could have affected by turnover. First, trade was liberalized during this period 
and, second, a social security reform was introduced in the early 1990's.

Colombia's trade liberalization during the early 1990's should be expected to have increased instability for workers employed in tradable sectors after 1990. Nonetheless, trade shocks should have affected formal and informal firms alike and, hence, differences-indifferences should control for the effect of these shocks on turnover. If, however, formal firms were more likely to produce in tradable sectors and informal firms in non-tradable sectors, then differences-in-differences would yield upwardly biased estimates of the firing cost effect. Below, I estimate differences-in-differences across sectors to identify whether the changes in turnover were greatest in tradable sectors. There are two reasons to believe, however, that the trade shocks did not generate the differences in turnover over time presented below. First, the next section shows no consistent pattern across sectors in the differences-in-differences estimates. In addition, differences-in-differences for different firm sizes and age groups show that the change in turnover was greatest for large firms and middle age workers who should have been affected most by the changes in job security legislation, but not by trade shocks.

The social security reform introduced during the early 1990's affected formal firms but not informal firms. Thus, the social security reform introduced a shock affecting formal and informal firms differentially over time. As described above, the social security reform increased employers' health and pension contributions and, thus, increased non-wage labor costs for firms complying with the legislation. The increased variable costs should have reduced hiring and should have had no effect on dismissals in the formal sector relative to the informal sector. This means that the social security reform should had generated very different effects on turnover 
from those predicted by a reduction in firing costs and from those reported in the next section. ${ }^{14}$ Moreover, if firms adjusted to the increased non-wage labor costs by reducing wages, then the social security reform should not have had any turnover effects. There is evidence that employers tend to pass on their non-wage costs to workers as lower wages. For example, Gruber (1997) shows the sharp reduction payroll taxes that followed the privatization of Chile's social security system had no employment effects because wages adjusted fully to the change in nonwage costs. Moreover, differences-in-differences across different firm sizes and age groups show that turnover changed most among larger firms and middle age workers who should had been affected most by the changes in job security legislation, but not by the social security reform.

\section{Empirical Analysis}

This section examines the impact of the Colombian labor market reform of 1990, which included a substantial reduction in severance payments, on the hazard rates out of employment and out of unemployment of formal sector workers relative to informal sector workers.

\section{A. The Data}

\section{A.1 Description}

The data to analyze the effects of the reform on the exit rates out of employment and out of unemployment are drawn from the Colombian National Household Surveys (NHS) for June of 1988, 1992, and 1996. The June NHS's were administered in seven metropolitan areas, including: Barranquilla, Bogota, Bucaramanga, Cali, Manizales, Medellin, and Pasto. The benefit of using the June surveys is that these include information on informality that allows to

\footnotetext{
${ }^{14}$ See Kugler, Jimeno and Hernanz (2003) for an analysis of the differential effects of firing costs and payroll taxes on turnover and employment.
} 
separate workers between formal sector workers (covered) and informal sector workers (uncovered). The June surveys allow defining workers as covered and uncovered in two ways. First, formal (covered) workers are defined as those workers whose employers make social security contributions and informal (uncovered) workers are defined as those whose employers do not contribute to the social security system. This definition is a useful one, because whether the employer contributes or not to social security is a good proxy of whether the employer generally complies or not with labor legislation. Second, formal (covered) workers are defined as wage-earners employed in firms with more than ten employees, and informal (uncovered) workers as wage-earners employed in firms with less than ten employees, family workers, domestic workers and the self-employed workers (excluding professionals and technicians). As discussed above, employers with five or less employees, family workers, and the self-employed are all exempt from severance pay legislation and domestic workers and workers in firms with low levels of capital are entitled only to half the amount of severance pay received by other employees. These surveys also include information on gender, age, marital status, educational attainment, number of dependents, city and sector of employment, that allows controlling for differences in turnover due to differences in characteristics across individuals. In addition, the surveys include information about whether the worker is permanent or temporary, which allows distinguishing the effect that the legislative change on temporary contracts had on turnover.

Table 3 presents summary statistics for the covered and uncovered groups (using the two definitions), before and after the reform. Columns 1 and 2 present the characteristics of formal (covered) workers and Columns 3 and 4 present the characteristics of informal (uncovered) workers, before and after the reform, respectively. Under both definitions, covered workers have more education, are slightly younger, have larger families, and are more likely to be married and 
female and to have a permanent contract than uncovered workers. However, aside from the differences in educational attainment, the differences in characteristics between the two groups are small. In addition, the changes in characteristics of the two groups between the pre-1990 and the post-1990 periods have moved in the same direction and are similar in magnitude. Educational attainment, average age, and the share of married workers increased in both groups after 1990, while the share of men, the size of households, and the share of workers with permanent contracts decreased in both groups after 1990.

These summary statistics suggest that differences in composition between the groups are not substantial. Nonetheless, the differences in characteristics may account for part of the changing turnover patterns and, thus, raw differences in turnover between covered and uncovered groups should be interpreted carefully. For this reason, in the analysis below I estimate formal hazard models that allow controlling for individual characteristics. The use of these models is, thus, crucial for identifying the firing cost effect of the labor market reform. Another source of compositional bias may arise if, as highlighted by the model, the composition of firms changes over time. Table 3 shows an increase in the size of the formal (covered) sector after 1990, according to both definitions. The percentage of workers in the formal sector increased from $44.84 \%$ to $51.05 \%$, according to definition 1 , and from $41.47 \%$ to $45.22 \%$ according to definition 2 , between the pre- and post-reform periods. The increase in the size of the formal sector, thus, indicates the importance of controlling also for firm characteristics, as the composition of formal firms may have also changed. Although the NHS's have little information on firm characteristics, the hazard models below do control for industry affiliation. Moreover, the fact that the increase in the size of the formal sector was small and that it cannot 
be directly attributed to the reform suggests that the selection biases described above may not be of great concern.

\section{A.2. Sampling Plan}

The June NHS's include information on tenure on the current job (in years) and on the duration of unemployment (in months) right before entering the current job that allow estimating hazard rates. In particular, the survey asks currently employed workers: How long have you been working on your current job?, and How long were you unemployed between your current job and your previous job? The data, thus, provides information on incomplete employment spells of currently employed workers, and on complete unemployment spells of workers who are currently employed and had a previous job (see graph below).

\section{June Waves:}

Employment Spell

Unemployment Spell
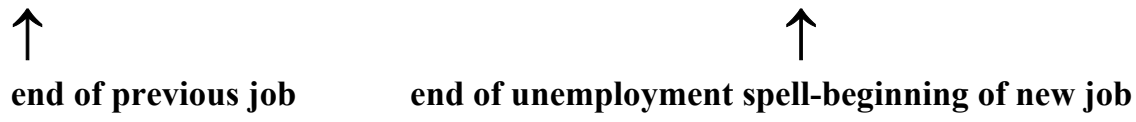

The stock sampling for the employment spells generates two types of biases. First, the sampled employment spells are too short because of the sampling of incomplete employment spells. In particular, Heckman and Singer (1985) show that under the assumptions of a time homogenous environment, no heterogeneity, and independence between employment and unemployment spells, the completed spells would be on average twice as long. Second, as a consequence of sampling currently employed workers, the incomplete employment spells are 
longer than the completed spells from a sample that follows workers flows from job-to-job over time. Thus, the sampling of currently employed workers introduces length bias. Heckman and Singer (1985) show, however, that under the assumptions stated above and, in addition, under the assumption of no duration-dependence the two biases exactly cancel out. Below, I estimate exponential hazard models that impose these assumptions.

Similarly, the stock sampling of the unemployment spells may also introduce a number of biases. Although the data provides complete unemployment spells, the fact that the spells are drawn from a sample of workers who are currently employed and had a previous job may generate biased estimates. First, sampling currently employed workers introduces length bias. This is because one oversamples workers with short spells relative to long spells. Thus, the mean of the sampled spells would be shorter than the mean of the spells from a flow sample. Second, sampling workers who had a previous job excludes all new entrants into the labor force and this introduces another type of length bias. By excluding new entrants from the sample, one oversamples workers with long spells relative to short spells, implying that the mean of the sampled spells would be shorter than the mean of the spells from a flow sample. Although, the distribution of unemployment spells obtained from this sampling plan is likely to be distorted, the bias due to stock sampling may be small in practice because the two biases have opposite signs and they may thus cancel out.

\section{B. Tenure and Unemployment Spells, Before and After the Reform}

\section{Average Tenure}

The model presented above indicates that the direct and indirect effects of the reduction in firing costs introduced by the reform should have increased the exit rates out of employment for formal workers relative to informal workers. The reform should have, thus, reduced the 
average tenure of workers covered by the reform (formal workers) relative to the tenure of uncovered workers (informal workers). ${ }^{15}$

Table 4 presents the average tenure for the covered and uncovered groups (using the first definition), before and after the Colombian Labor Market Reform of $1990 .{ }^{16}$ The first row corresponds to the average tenure after the reform, the second row corresponds to the average tenure prior to the reform, and the third row to the differences. The last row provides the differences-in-differences estimate of the effect of the reform on tenure. The average tenure of covered workers decreased after the reform from 5.6002 to 5.3130 years. The decrease in average tenure for covered workers was of 3.4452 months and significantly different from zero. In contrast, the decrease in average tenure for uncovered workers was of 0.2112 months and not significantly different from zero. The differences-in-differences estimate of the effect of the reform was a reduction in average tenure of 3.6612 months. The effect is large, significantly different from zero, and, as predicted by the theory, most of the change comes from the reduction in average tenure of covered workers rather than from the increase average tenures of uncovered workers. Table 5 presents the difference-in-differences estimates of the reform on average tenure by gender. This table shows that most of the change in the aggregate figures is driven by the effect of the reform on men's tenures. The differences-in-differences estimate of the effect of the reform was a reduction of 4.1208 months for men and of 2.1012 months for women, although the effect is not significantly different from zero for women.

Tables 6 and 7 present differences-in-differences estimates of the reform for different age and education groups. Table 6 shows that the effect of the reform was greatest for middle age

\footnotetext{
15 In particular, the average tenure of formal workers should decrease because the fraction of workers with short tenures (those just hired) increases and/or the fraction of workers with long tenures (those just fired) decreases.

${ }^{16}$ This section and the rest of the analysis relies on the first definition of formal/informal since the two measures are highly correlated and the
} 
workers. The differences-in-differences estimate of the effect was a reduction of 4.0176 months for middle age workers, while the estimates for young and older workers were not significantly different from zero. These results are consistent with the change in severance pay legislation and with the change in 'unjust' dismissal legislation that raised the cost of 'unjustly' dismissing workers with more than ten years of tenure. In particular, the change in the legislation should have induced firms to dismiss workers just prior to completing ten years of tenure. This result is confirmed in the next section with the formal hazard analysis. In contrast, Table 7 shows that the difference-in-differences estimates of the effects of the reform were greatest for employees with primary education and with a university degree or more. This result, however, inverts in the formal hazard analysis that controls for changes in turnover for these groups after the reform.

Table 8 shows the differences-in-differences estimates of the effect of the reform by sector, to identify whether the reduction in tenures could had been the result of trade liberalization. This table shows that the difference-in-differences estimates for agriculture, mining, manufacturing, construction, and commerce are not significantly different from zero at conventional levels. Moreover, the differences-in-differences estimate of the reform was a reduction of 6.4836 months in transportation, but only significant at the $10 \%$ level, a reduction of 10.7028 months in financial services, only significant at the 5\% level, and a reduction of 10.236 months in services, significant at the $1 \%$ level. Thus, the estimates by sector do not show a consistent pattern of changes across tradable and non-tradable sectors. These results are confirmed by the formal hazard analysis presented below. Moreover, consistent with the changes predicted by the labor market reform, the changes that are significant are driven by 
reductions in the tenures of covered workers and not by the increase in tenures of uncovered workers.

Table 9 shows the differences-in-differences estimates by firm size. The results show that the effects of the reform were greatest for larger firms, as predicted by the changes in the legislation. The differences-in-differences estimates for the self-employed and for workers employed in firms with 2-5 employees and in firms with 5-10 employees are not significantly different from zero. In contrast, the estimate of the effect of the reform for workers employed in firms with more than ten employees was a reduction of 6.3372 months. The effect of the reform on workers employed by large firms is big, significantly different from zero, and driven mainly by a reduction of tenures of covered workers rather than by an increase of the tenures of uncovered workers. This evidence is strongly consistent with the expected effects of a reduction in firing costs, since the self-employed and workers employed in firms with less than 5 employees are completely exempt from severance and workers employed in firms with little capital are only entitled to partial severance payments.

\section{Unemployment Duration}

The model predicts that a reduction in dismissal costs should increase the exit rate out of unemployment and into formal jobs relative to the exit rate out of unemployment and into informal jobs. Thus, the reduction in severance payments would be expected to shorten unemployment spells of workers hired into formal jobs relative to those of workers hired into informal jobs. ${ }^{17}$

\footnotetext{
${ }^{17}$ In particular, the average unemployment spell of those going into formal jobs should decline because of the increased probability of being hired into a formal firm should reduce the fraction of workers with long spells. Moreover, the fraction of workers with short spells (those just fired from formal jobs) increases.
} 
Table 10 presents the differences-in-differences estimates of unemployment spells. ${ }^{18}$ The average unemployment spell for workers whose spell ended with a formal sector job increased. However, the average unemployment spell of workers whose spell ended in an informal sector job lengthened by even more than that of formal workers. Thus, the differences-in-differences estimate was a reduction in the average unemployment spell of 3.1108 weeks and significantly different from zero. ${ }^{19}$ Table 11 presents the results for men and women, separately. The differences-in-differences estimate for men was not significantly different from zero, but the effect on women was a shortening of the average unemployment spell of 7.9672 weeks and significant at the $1 \%$ level. Table 12 presents the differences-in-differences estimates for different age groups and Table 13 presents the differences-in-differences estimates for different education groups. The results show that unemployment spells decreased most for young and middle aged workers. This result is consistent with the expectation that a decrease in firing costs should increase hiring, especially for outsiders, and is also confirmed in the formal hazard analysis below. Moreover, Table 13 shows that the differences-in-differences estimates are greatest for workers with incomplete secondary and incomplete university education. Thus, the firing cost effect on hiring appears to be greater on workers that are risky hires. This is also confirmed below by the formal hazard analysis.

Table 14 presents the differences-in-differences estimates of the effect of the reform on unemployment spells by industry. The differences-in-differences estimates are not significantly different from zero in agriculture, mining, manufacturing, utilities, construction, transportation,

\footnotetext{
${ }^{18}$ Unemployed workers are defined as formal if the job subsequent to their spell was in the formal sector and as informal if their job subsequent to the spell was in the informal sector.

${ }^{19}$ Contrary to the results for tenure, the differences-in-differences results for unemployment spells are driven mainly by the lengthening of the spells of those exiting into the informal sector. This is however, consistent with the model presented above. On the one hand, the model predicts that the probability of being hired in the formal sector should rise after the reform because of the increase in the number of firms producing in this sector. On the other hand, the probability of being hired into the informal sector falls unambiguously.
} 
and financial services. Only the effect on commerce and services are significantly different from zero. The differences-in-differences estimate of the effect of the reform was a reduction of 1.2746 weeks of the unemployment spell in commerce, but only significant at the $5 \%$ level and a reduction of 1.3126 weeks of the unemployment spell in services, significant at the $1 \%$ level. Thus, as for tenure, the results do not show a consistent pattern of a differential impact on tradable and non-tradable sectors. In contrast, the differences-in-differences estimates by firm size in Table 15 provide some evidence that the firing cost effect was greatest among larger

firms. In particular, the differences-in-differences estimates of the reform on firms with $5-10$ employees and on firms with more than ten employees indicate reductions of the average unemployment spell of 0.8038 weeks and of 0.2913 weeks, respectively. Although neither effect is significant at conventional levels, the p-values for the differences-in-differences estimates of larger firms are greater than the p-values for the estimates of the self-employed and of firms with 2-5 employees.

\section{Employment and Unemployment Survivor Functions, Before and After the Reform}

While the previous section presented the implied effects of the reform on tenure and unemployment spells, this section presents evidence on the effects of the reform on the survival probabilities in employment and unemployment. If the reduction of dismissal costs introduced by the reform, indeed, was important, then the probability of survival in a formal job should had fallen after the reform relative to the probability of survival in an informal job. In addition, if the reduction in dismissal costs generated more hiring, then the probability of survival in unemployment should had fallen after the reform for workers exiting into formal jobs relative to those exiting into informal jobs. 
Figure 1 presents the Kaplan Meier survival estimates for employment. This figure includes the probabilities of survival for formal and informal workers before and after the reform. The figure shows that the probability that a formal job lasts more than two years decreased after the reform. For tenures of more than two years, the survivor function of formal workers after the reform (Formal/Post-1990) shifts down with respect to the survivor function of formal workers before the reform (Formal/Pre-1990). However, for tenures of less than two years, the survivor function of formal workers after the reform shifted up with respect to the survivor function of formal workers before the reform. That survivor function is greater for formal workers with less than two years of tenure after the reform is surprising, given the extension by the reform of the use of temporary contracts for less than a year. However, this shift in the survivor function for those with less than two years of tenure may simply reflect the greater hiring of new permanent workers after the reform, as is shown below in the estimation of formal hazard models. The downward shift of the survivor function of formal workers after the reform is consistent with the reduction in dismissal costs for formal firms after the reform. In contrast, however, Figure 1 shows, that the probability of survival increased slightly for informal workers after the reform relative to informal workers prior to the reform. The survivor function of uncovered workers after the reform (Informal/Post-1990) shifted up slightly with respect to the survivor function of uncovered workers before the reform (Informal/Pre-1990). If common shocks to both groups were responsible for the decreased probability of survival of formal jobs, then the figure should also show a downward shift of the survivor function for informal workers. Moreover, consistent with the fact that formal workers are covered by job security regulations while informal workers are not, the survivor functions for formal workers are higher than the survivor functions of informal workers both before and after the reform. The survivor functions 
for the covered and uncovered groups, as well as the shifts of the survivor functions for each group after the reform, are, thus, consistent with the predicted effects of firing costs and with the predicted effects of the reform on formal turnover.

Standard Kaplan-Meier survival functions of unemployment show a similar change after the reform. Figure 2 shows that the unemployment survival functions of formal hires shifted down between the pre-reform (Formal/Pre-1990) and post-reform (Formal/Post-1990) periods. Thus, for every unemployment spell of duration $t$, the probability of remaining unemployed decreased after the reform for those who exited into formal employment. On the contrary, Figure 2 shows that the unemployment survival functions increased slightly for informal workers, after the reform. These shifts are consistent with the expected effects of the reform. The reduction of firing costs would have predicted that the probability of remaining unemployed at every time $t$ should have decreased for workers covered by the reform but not for uncovered workers. Moreover, the next section shows, that the escape rates into and out of unemployment increased for formal workers relative to informal workers, even after controlling for observable characteristics.

\section{Formal Hazard Models}

It is possible that the employment and unemployment spells and the survivor functions presented above changed after the reform due to changes in the characteristics of workers and jobs after 1990. Thus, below I estimate formal duration models that allow controlling for the effects of changes in worker and job characteristics on exit hazard rates.

As described in Section IV, I estimate exponential hazard models that control for age, education, marital status, city, industry of employment, and the number of dependents. More importantly, these formal hazard models can capture the effects of the reform. The models 
include a Formal dummy that controls for differential turnover patterns across groups, a Post90 dummy that captures the differential turnover pattern in turnover after 1990 for all groups, and an interaction term of the Formal and Post90 dummies that captures the effect of the reform. In particular, the coefficient of the interaction term can be interpreted as the differential hazard rates of covered workers after the reform was introduced. Moreover, to further probe the importance of the reform, other specifications of the model are included to test whether the effects of the reform showed the expected patterns for different groups. In addition, to test the importance of trade shocks, a specification of the model that includes interaction terms of the Formal $\times$ Post 90 dummy with sector dummies is also estimated.

Table 16 shows the results of the estimation of exponential exit hazard rates out of employment. Column (1) presents the estimates obtained from the basic specification of the model that includes the covariates mentioned above, the Formal dummy, the Post90 dummy, and the interaction term of the two. The results show the expected signs. The hazards are higher for younger, more educated, female, and single workers and for workers with smaller number of dependents. The results also show that the hazards out of employment decreased during the post-1990 period for informal workers. Moreover, as expected, formal workers, who are covered by the legislation, have lower hazards out of employment than do informal workers. Most importantly, the coefficient on the interaction term is positive and significant at the $1 \%$ level. In particular, the coefficient indicates that, after the reform, covered workers are $6.17 \%$ more likely to exit employment than are uncovered workers. This result, thus, suggests that the reduction in firing costs introduced by the reform increased the exit rates out of employment substantially. Exit hazards out of employment are likely to have increased after the reform both because of the 
increase in dismissals and because of the increase in quits resulting from greater hiring after the reform.

Another essential feature of the reform was the greater flexibility in the use of temporary (fixed-term) contracts and, thus, one may suspect that a great deal of the increases in turnover after the reform may simply be the result of increased hiring of temporary workers in the formal sector. The specification in Column (2) allows to distinguish whether the increase in the exit rates out of employment was purely the result of the increase in the use of temporary contracts or if the reduction in the cost of firing permanent workers also played a role. Column (2) in Table 16 presents the estimates of a model including, a permanent dummy, an interaction term of the Post90 dummy and the permanent dummy, an interaction term of the Formal dummy and the Permanent dummy, and an interaction of the Formal $\times$ Post90 dummy with the Permanent dummy. $^{20}$ All the coefficients have the same signs as before and the coefficient on the Permanent dummy is negative and significant at the $1 \%$ level, as expected. The results show that the coefficient on the Formal $\times$ Post90 interaction is positive, but the interaction term of the Formal $\times$ Post90 dummy with the Permanent dummy is negative and significant at the $1 \%$ level. The results indicate that, after the reform, the probability of exiting employment was $6.7 \%$ higher for temporary workers in the formal sector than for temporary workers in the uncovered sector. At the same time, the probability of exiting employment was $6.1 \%$ higher for permanent worker in the formal sector than for permanent workers in the uncovered sector after the reform. Thus, while the introduction of temporary contracts does appear to explain part of the increased turnover of formal workers, the results also suggest that the reduction of dismissal costs for permanent workers also contributed to increasing turnover. 
Column (3) in Table 16 presents the results of specifications including interaction terms of the reform effect with the age and education variables. This specification of the model allows seeing whether the impact of the reform was greater on the groups that would be expected to be affected most by the changes in the legislation. First, since the reform increased the costs of dismissing workers with more than ten years of tenure, then the impact of the reform would be expected to be greater for groups with less than ten years of tenure (i.e., younger workers). Second, the special contracts introduced by the reform, which exempted workers with more than ten times the minimum wage from severance payments, would be expected to affect mostly the turnover of highly educated workers who are likely to earn more than ten times the minimum wage. Column (3) shows that, indeed, the hazard rates of younger and middle-aged workers increased by more than the hazards of older workers. Young workers with secondary education hired in the formal sector were $4.1 \%$ more likely to exit employment than did younger informal workers with secondary education after the reform. Similarly, middle-aged formal workers with secondary education were $7.9 \%$ more likely to exit employment than did middle-aged informal workers with secondary education after the reform. The smallest impact of the reform was on older formal workers, who were only $1.8 \%$ more likely to exit employment than did older informal workers after the reform. These results are thus consistent with lower expected dismissals of workers with more than ten years of tenure. Moreover, the results also indicate that the impact of the reform was greater on more educated workers who are more likely to have benefited from the use of "Integral Salary" contracts. The exit rate of middle-aged formal workers with a primary education increased by $6.6 \%$ after the reform relative to middle-aged informal workers with the same level of education. The exit rate of middle-aged formal workers

\footnotetext{
${ }^{20}$ The permanent dummy takes the value of 1 if the worker is a permanent worker and zero if the worker is temporary.
} 
with secondary, a high school degree and university education increased by $7.9 \%, 12.5 \%$, and $13.1 \%$ after the reform relative to middle-aged informal workers with the same levels of education. In contrast, the hazard out of employment increased only by $3.8 \%$ for middle-aged formal workers with more than a university degree after the reform relative to middle-aged informal workers with the highest educational attainment. The impact was, thus, smallest among the least and the most educated. The small impact on these groups may be due to the fact that these workers have longer tenures and, thus, are more likely to have been affected by the increase in the costs of 'unjust' dismissals for tenures of more than ten years.

While the above patterns are consistent with the effects of the labor market reform on different groups, it may be that part of the increased turnover is the result of trade shocks affecting various groups differently. Column (4) in Table 16 presents the results from an exponential hazard model that includes interaction terms of the Formal $\times$ Post90 dummy with sector dummies. The idea is that if trade liberalization were responsible for the increased turnover after the labor market reform, then the observed impact would be greater on workers employed in tradable sectors than on those employed in non-tradable sectors. The results from Column (4) in Table 16 show that the increase in turnover of covered workers after the reform was greater in utilities, transportation, construction and services. The probability of exiting formal employment in these sectors after the reform was $640 \%, 15.7 \%, 12.3 \%$, and $17.6 \%$ greater than the probability of exiting informal employment in these sectors. However, if the trade shocks were a main source of the increased turnover, it would be expected that the exit rate out of employment would had increased more for workers hired in trade-intensive sectors such as commerce and manufacturing. In fact, after the reform formal workers in commerce were only $2.5 \%$ more likely to exit employment than informal workers in this sector were. Moreover, 
the probability of exiting employment was $1 \%$ lower after the reform for formal workers relative to informal workers hired in manufacturing. The results from the exponential hazard model, thus, do not provide any reason to believe that trade liberalization increased turnover for covered workers after 1990.

Table 17 includes the results of exponential hazards out of unemployment. Given the reduction of mandated firing costs, one would expect greater hiring in the covered sector and, thus, an increase in the escape rate out of unemployment for workers hired into formal sector jobs. Column (1) shows that, indeed, the exit hazard out of unemployment increased by 5.75\% for covered workers after the reform relative to uncovered workers. ${ }^{21}$ Moreover, while the extension of temporary contracts appears to explain part of the increased hiring, most of the increase in the exit hazards out of unemployment is due to the increased hazards into permanent jobs in the formal sector. The results from Column (2) in Table 17 show that the escape rate out of unemployment increased by $4 \%$ for formal temporary workers after the reform relative to temporary informal workers. However, the exit rate out of unemployment increased by even more for formal permanent workers after the reform, thus indicating that the reduction in dismissal costs of permanent workers did increase the incentives to hire this type of workers. The results show that the probability of exiting unemployment and entering a formal permanent job increased by $6.1 \%$ after the reform relative to the probability of entering an informal permanent job. ${ }^{22}$

Column (3) in Table 17 presents the results of the exponential hazard model including interaction terms of the reform effect with the age and education variables. The estimates from

\footnotetext{
${ }^{21}$ The sign on the formal dummy is positive and significant at the $1 \%$ level. This could be explained if unsuccessful discouraged workers who get tired of searching for formal work turned to the informal sector as a last resource.
} 
this model show that, as for the hazards out of employment, the impact of the reform was greater on younger and more educated workers. The reform should have had greater effects on the exit rates out of unemployment for younger workers if the reduction in dismissal costs decreased the power of insiders and induced more hiring of young outsiders. In fact, the exit rate out of unemployment and into formal jobs for young workers increased by $25.8 \%$ after the reform relative to the exit rate into informal jobs. The exit rate into formal jobs for middle-aged workers also increased after the reform but not by as much. In particular, the hazard rate out of unemployment and into formal jobs increased by $3.9 \%$ for middle-aged workers relative to informal workers. In contrast, the hazard rates out of unemployment and into formal jobs decreased by $11.1 \%$ for older workers after the reform, relative to those entering informal jobs. In addition, these results show that the impact of the reform on exit hazard rates out unemployment was greatest on the more educated. This is to be expected, given that these workers are the ones more likely to opt for the "Integral Salary" contract that exempts workers from severance and other dismissal costs. In fact, the hazards out of unemployment and into formal jobs decreased after the reform by $10 \%$ relative to the hazard out of unemployment and into informal jobs for workers with primary education and by $3.9 \%$ and $1.2 \%$ for workers with secondary schooling and a high school degree, respectively. In contrast, after the reform, the exit rates out of unemployment and into formal jobs increased by $37 \%$ for university graduates and by $12 \%$ for workers with more than a university degree relative to the exit rates into informal jobs.

Finally, Column (4) in Table 17 shows the results of the hazard model with sector dummy and reform interactions. The results show that the increase in the exit rates out of

\footnotetext{
${ }^{22}$ The sign on the permanent dummy is positive and significant at the $1 \%$ level. Similarly to the description in footnote 17 , this is probably due
} 
unemployment after the reform was greater for workers exiting into formal sector jobs in mining, utilities, and services. The probability of exiting unemployment into formal employment in these sectors after the reform was $45.7 \%, 27.6 \%$, and $10.9 \%$ greater than the probability of exiting unemployment into informal employment in these sectors. However, the probability of exiting unemployment into formal employment in trade-intensive sectors such as commerce and manufacturing was only $2.8 \%$ and $6.7 \%$ higher than the probability of exiting unemployment into informal employment in these sectors. As the results from the employment hazard models, these results from the unemployment hazard model, thus, do not provide evidence indicating the importance of trade liberalization in increasing worker turnover after 1990. Instead, the increased hazards in utilities and services, which are more likely to be public sector jobs covered by the legislation, indicates to the importance of the labor market reform in generating these patterns in turnover.

\section{Worker Turnover and Unemployment}

The previous section showed that the functioning of labor markets changed substantially in Colombia after the introduction of the labor market reform of 1990 . In particular, the estimates from the formal hazards show that, after controlling for observable characteristics, the post-reform period was characterized by higher exit rates into and out of unemployment in the formal sector relative to the informal sector.

While the results in the previous section indicate that the reform increased labor market flexibility by increasing the flows into and out of unemployment, the net effects of the reform on employment and unemployment are ambiguous. In this section, I use the steady state condition of the model in Section IV, together with the hazard rate results obtained in Section VI, to obtain

discouraged workers who are unsuccessful finding a permanent position turning to temporary jobs as a last resource. 
a rough estimate of the net effect of the reform on unemployment.

In the model above, a steady state condition has to be satisfied such that the flow into unemployment from both sectors must equal the flow out of unemployment and into both sectors:

$$
\left.\lambda_{\mathrm{F}} \mathrm{e}_{\mathrm{F}}+\theta \mathrm{q}(\theta)\left(1-\mathrm{F}\left(\mathrm{A}_{\mathrm{m}}\right)\right) \mathrm{G}\left(\bar{\gamma}_{\mathrm{F}}\right)\right) \mathrm{u}+\lambda_{\mathrm{I}} \mathrm{e}_{\mathrm{I}}+\theta \mathrm{q}(\theta) \mathrm{F}\left(\mathrm{A}_{\mathrm{m}}\right) \mathrm{G}\left(\bar{\gamma}_{\mathrm{I}}\right) \mathrm{u}=\theta \mathrm{q}(\theta)\left(1-\mathrm{F}\left(\mathrm{A}_{\mathrm{m}}\right)\right) \mathrm{u}+\theta \mathrm{q}(\theta) \mathrm{F}\left(\mathrm{A}_{\mathrm{m}}\right) \mathrm{u}
$$

Substituting for employment in each sector, $e_{F}=\left(1-F\left(A_{m}\right)\right) e$ and $e_{I}=F\left(A_{m}\right)$ e, and for the identity, $\mathrm{e}+\mathrm{u}=1$, and solving for $\mathrm{u}$ yields the following formula for the unemployment rate,

$$
\begin{gathered}
\mathrm{u}=\left[\left(1-\mathrm{F}\left(\mathrm{A}_{\mathrm{m}}\right)\right) \lambda_{\mathrm{F}}+\mathrm{F}\left(\mathrm{A}_{\mathrm{m}}\right) \lambda_{\mathrm{I}}\right] / \\
{\left[\left(1-\mathrm{F}\left(\mathrm{A}_{\mathrm{m}}\right)\right) \lambda_{\mathrm{F}}+\mathrm{F}\left(\mathrm{A}_{\mathrm{m}}\right) \lambda_{\mathrm{I}}+\left(1-\mathrm{F}\left(\mathrm{A}_{\mathrm{m}}\right)\right) \theta \mathrm{q}(\theta)\left(1-\mathrm{G}\left(\bar{\gamma}_{\mathrm{F}}\right)\right)+\mathrm{F}\left(\mathrm{A}_{\mathrm{m}}\right) \theta \mathrm{q}(\theta)\left(1-\mathrm{G}\left(\bar{\gamma}_{\mathrm{I}}\right)\right)\right] .}
\end{gathered}
$$

The unemployment rate can be estimated from this equation by substituting for the average hazard rates into and out of unemployment during the pre-reform period and the shares in each sector. The average hazard rates are estimated with the average tenure and unemployment spells in Tables 4 and 10, which indicate an average tenure of 67.2 and 54.2 months in the formal and informal sectors and average unemployment spells of 1.8 and 2.2 months in the formal and informal sectors during the pre-reform period. The shares of formal and informal employment are reported in Table 1. Before the reform, the shares of formal and informal employment were 0.45 and 0.55 , respectively. After the reform, the shares of formal and informal employment changed to 0.51 and 0.49 , respectively. Finally, Tables 16 and 17 show an increase in the hazards into an out of unemployment of $6.17 \%$ and $5.75 \%$.

As the model abstracts from many factors affecting labor markets, the estimated unemployment obtained from the formula above should not be interpreted as precise estimates of the unemployment rate, but rather as an indication of the magnitude of the changes in unemployment rates between the two periods. For example, taking into account other flows such 
as retirements, new entries into the labor market, and deaths, the unemployment rate is:

$$
\begin{gathered}
\mathrm{u}=\left[\xi+\psi+\sigma+\left(1-\mathrm{F}\left(\mathrm{A}_{\mathrm{m}}\right)\right) \lambda_{\mathrm{F}}+\mathrm{F}\left(\mathrm{A}_{\mathrm{m}}\right) \lambda_{\mathrm{I}}\right] / \\
{\left[\xi+\psi+\sigma+\left(1-\mathrm{F}\left(\mathrm{A}_{\mathrm{m}}\right)\right) \lambda_{\mathrm{F}}+\mathrm{F}\left(\mathrm{A}_{\mathrm{m}}\right) \lambda_{\mathrm{I}}+\left(1-\mathrm{F}\left(\mathrm{A}_{\mathrm{m}}\right)\right) \theta \mathrm{q}(\theta)\left(1-\mathrm{G}\left(\bar{\gamma}_{\mathrm{F}}\right)\right)+\mathrm{F}\left(\mathrm{A}_{\mathrm{m}}\right) \theta \mathrm{q}(\theta)\left(1-\mathrm{G}\left(\bar{\gamma}_{\mathrm{I}}\right)\right)\right],}
\end{gathered}
$$

where $\xi, \psi$, and $\sigma$ are the flows due to retirements, new entries, and deaths, which are estimated assuming a working life of 35 years, entry at 18 years of age, and a life expectancy of 60 years for those that die before retiring.

The unemployment rate for the pre-reform period obtained with this formula is $4.84 \%$, which is lower than the true unemployment rate of $11.8 \%$ in Colombia in 1988 . The post-reform unemployment rate estimated with the post-reform shares is $4.69 \%$, which is also a lower than the true unemployment in 1992 and 1996,10.2\% and 10\%, respectively. These results suggest a reduction in unemployment of $0.15 \%$ points between the pre- and post-reform periods, compared to the actual reduction in unemployment of $1.6 \%$ between 1988 and 1992 and of $1.8 \%$ between 1988 and 1996 . These results suggest the reform contributed to about $10 \%$ of the reduction in the unemployment rate between the pre- and post-reform periods.

\section{Conclusion}

The Colombian labor market reform of 1990 provides an interesting quasi-experiment to analyze the effects of a reduction in firing costs. This study exploited the temporal change in the legislation together with the difference in coverage between formal and informal workers to analyze the impact of the reform on worker turnover. The differences-in-differences estimates indicate that the reform increased the dynamism of the Colombian labor market, by increasing the exit rates into and out of unemployment. Moreover, aside from contributing to increase mobility in the labor market, the reform is also likely to have contributed to increase compliance with labor legislation by lowering the costs of formal production. The increased churning in the 
labor market and the greater compliance with the legislation are estimated to have contributed to about $10 \%$ of the reduction in the unemployment rate from the late 1980 's to the early 1990 's. At the same time, the reform is likely to explain in part the recent surge in the unemployment rate during the late 1990's. This is because the greater flexibility in hiring and firing after the reform is likely to translate in increased hiring relative to firing during expansions but in increased firings relative to hiring during recessions. 


\section{References}

Acemoglu, Daron and Joshua Angrist. 2001. "Consequences of Employment Protection? The Case of the Americans with Disabilities Act," Journal of Political Economy, 109(5): 915-57.

Anderson, Patricia. 1993. "Linear Adjustment Costs and Seasonal Labor Demand: Evidence from Retail Trade Firms," Quarterly Journal of Economics, 108(4): 1015-42.

Angrist, Joshua and Adriana Kugler. 2003. "Protective or Counter-Productive? Labor Market Institutions and the Effect of Immigration on EU Natives," Economic Journal, 113: F302-F331.

Autor, David. 2003. "Outsourcing at Will: Unjust Dismissal Doctrine and the Growth of Temporary Help Employment,” Journal of Labor Economics, 21(1): 1-42.

, John J. Donohue III and Stewart J. Schwab. 2003. "The Costs of WrongfulDischarge Laws," NBER Working Paper No. 9425.

Bentolila, Samuel and Juan J. Dolado. 1994. "Labour Flexibility and Wages: Lessons from Spain," Economic Policy, 9(181): 53-99.

and Giuseppe Bertola. 1990. "Firing Costs and Labor Demand: How Bad is Eurosclerosis," Review of Economic Studies, 57(3): 381-402.

Bentolila, Samuel and Gilles Saint-Paul. "The Macroeconomic Impact of Flexible Labor Contracts, with an Application to Spain," European Economic Review, 36(5): 1013-1054.

Bertola, Giuseppe, Francine Blau and Lawrence Kahn. 2002. "Comparative Analysis of Labor Market Outcomes: Lessons for the US from International Long-Run Evidence," in Alan Krueger and Robert Solow, eds., The Roaring Nineties: Can Full Employment Be Sustained? New York: Russell Sage and Century Foundations.

Bertola, Giuseppe. 1990. "Job Security, Employment, and Wages," European Economic Review, 54(4): 851-79.

Burgess, Simon. 1988. "Employment Adjustment in UK Manufacturing," Economic Journal, 98(389): 81-104.

Di Tella, Rafael, and Robert MacCulloch. 2004. "Consequences of Labour Market Flexibility: Panel Evidence Based on Survey Data," forthcoming in European Economic Review.

Dertouzos, J. and L. Karoly. 1993. "Employment Effects of Worker Protection: Evidence from the U.S.," in C. Buechtermann, Employment Security and Labor Market Behavior. Ithaca, NY: ILR Press. 
Grubb, David and William Wells. 1993. "Employment Regulations and Patterns of Work in EC countries," OECD Economic Studies, 21: 7-39.

Gruber, Jonathan. 1997. "The Incidence of Payroll Taxation: Evidence from Chile," Journal of Labor Economics, 15(3): S72-S101.

Hamermesh, Daniel. 1993. "Employment Protection: Theoretical Implications and Some U.S. Evidence," in C. Buechtermann, Employment Security and Labor Market Behavior. Ithaca, NY: ILR Press.

Heckman, James and C. Pagés. 2000. "The Cost of Job Security Regulation: Evidence from Latin American Labor Markets," Economia, 1(1).

, and B. Singer. 1985. "Social Science Duration Analysis," in J. Heckman and B. Singer, eds., Longitudinal Analysis of Labor Market Data. Cambridge: Econometric Society Monograph Series.

and Richard Robb Jr. 1985. "Alternative Methods for Evaluating the Impact of Interventions," in J. Heckman and B. Singer, eds., Longitudinal Analysis of Labor Market Data. Cambridge: Econometric Society Monograph Series.

Hopenhayn, Hugo and Richard Rogerson. 1993. "Job Turnover and Policy Evaluation: A General Equilibrium Analysis," Journal of Political Economy, 101(5): 915-938.

Krueger, Alan. 1991. "The Evolution of Unjust Dismissal Legislation in the U.S.," Industrial and Labor Relations Review, 644-60.

Kugler, Adriana and Gilles Saint-Paul. 2004. "How do Firing Costs Affect Worker Flows in a World with Adverse Selection?," forthcoming Journal of Labor Economics, April.

Kugler, Adriana and Giovanni Pica. 2003. "Effects of Employment Protection and Product Market Regulations on the Italian Labor Market," IZA Working Paper No. 948.

Kugler, Adriana, Juan F. Jimeno and Virginia Hernanz. 2003. "Employment Consequences of restrictive Permanent Contracts: Evidence from Spanish Labor Market Reforms," CEPR Discussion Paper No. 3724.

Kugler, Adriana. 2002. "Severance Payments Savings Accounts: Evidence from Colombia," CEPR Discussion Paper No. 3197.

. 1999. The Impact of Firing Costs on Turnover and Unemployment: Evidence from the Colombian Labour Market Reform," International Tax and Public Finance, 6(3): 389410. 
Lazear, Edward. 1990. "Job Security Provisions and Employment," Quarterly Journal of Economics, 105(3): 699-726.

Lindbeck, Assar and Dennis Snower. 1988. "Cooperation, Harassment, and Involuntary Unemployment," American Economic Review, 78(1): 167-88.

and Marta Luz Henao. 1995. "Efectos Económicos y Sociales de la Legislación Laboral," Coyuntura Social, 13: 47-68.

Miles, Thomas. 2000. "Common Law Exceptions to Employment at Will and U.S. Labor Markets," Journal of Law, Economics, and Organization, 16(1): 74-101.

Nickell, Stephen and Richard Layard. 1999. "Labour Market Institutions and Economic Performance," in O. Ashenfelter and D. Card, eds., Handbook of Labor Economics, Vol.3. Amsterdam: North Holland.

Ocampo, José Antonio. 1987. "El Régimen Prestacional del Sector Privado," in José Antonio Ocampo and Manuel Ramírez, eds., El Problema Laboral Colombiano. Bogotá: Departamento Nacional de Planeación.

OECD. 1999. Employment Outlook. Paris: OECD Publications.

Oyer, Paul and Scott Schaefer. 2000. "Layoffs and Litigation," RAND Journal of Economics, 31(2): 345-58. 
Table 1: Indemnities for 'Unjust' Dismissal by Tenure

\begin{tabular}{|c|c|c|c|c|c|}
\hline \multicolumn{4}{|c|}{$\begin{array}{c}\text { Pre- And Post- } \\
\text { Reform }\end{array}$} & \multirow{2}{*}{$\begin{array}{c}\text { Pre-Reform } \\
\geq 10 \text { years }\end{array}$} & \multirow{2}{*}{$\begin{array}{c}\text { Post-Reform } \\
\geq 10 \text { years }\end{array}$} \\
\hline & Less than a Year & $\geq 1$ and $<5$ years & $\geq 5$ and $<10$ years & & \\
\hline \multicolumn{6}{|l|}{ Dismissal } \\
\hline Costs & 45 days & $\begin{array}{l}45 \text { days and } 15 \\
\text { Additional days } \\
\text { After the first } \\
\text { year. }\end{array}$ & $\begin{array}{l}45 \text { days and } 20 \\
\text { additional days } \\
\text { After the first } \\
\text { year. }\end{array}$ & $\begin{array}{l}45 \text { days and } 30 \\
\text { additional days } \\
\text { after the first } \\
\text { year. }\end{array}$ & $\begin{array}{l}45 \text { days and } 40 \\
\text { additional days } \\
\text { After the first } \\
\text { year. }\end{array}$ \\
\hline
\end{tabular}

Table 2: Advance Notice Requirements by Firm Size

\begin{tabular}{cc}
\hline \hline Firm Size & $\begin{array}{c}\text { Threshold for Advance } \\
\text { Notification of Collective } \\
\text { Dismissals }\end{array}$ \\
\hline$>10$ and $<50$ employees & $30 \%$ of the workforce \\
$\geq 50$ and $<100$ employees & $20 \%$ of the workforce \\
$\geq 100$ and $<200$ employees & $15 \%$ of the workforce \\
$\geq 200$ and $<500$ employees & $9 \%$ of the workforce \\
$\geq 500$ and $<1,000$ employees & $7 \%$ of the workforce \\
$\geq 1,000$ employees & $5 \%$ of the workforce \\
\hline \hline
\end{tabular}


Table 3: Basic Characteristics of Formal and Informal Workers, Before and After the Reform

\begin{tabular}{|c|c|c|c|c|}
\hline & \multicolumn{2}{|c|}{ Formal } & \multicolumn{2}{|c|}{ Informal } \\
\hline & Pre-reform & Post-reform & Pre-reform & Post-reform \\
\hline \multicolumn{5}{|l|}{$\begin{array}{l}\text { Definition } 1 \text { of } \\
\text { Informality }\end{array}$} \\
\hline $\begin{array}{l}\text { Share of Total } \\
\text { Employment }\end{array}$ & $44.84 \%$ & $51.05 \%$ & $55.16 \%$ & $48.95 \%$ \\
\hline $\begin{array}{l}\text { Share of Permanent } \\
\text { Workers }\end{array}$ & $90.66 \%$ & $88.84 \%$ & $77.64 \%$ & $74.5 \%$ \\
\hline Share of Men & $68.69 \%$ & $64.95 \%$ & $69.6 \%$ & $67.56 \%$ \\
\hline $\begin{array}{l}\text { Share of Married } \\
\text { Workers }\end{array}$ & $69.79 \%$ & $73.38 \%$ & $68.1 \%$ & $72.17 \%$ \\
\hline Average Education & 8.9 years & 9.74 years & 6.1 years & 6.67 years \\
\hline Average Age & 35.52 years & 35.87 years & 36.01 years & 36.54 years \\
\hline $\begin{array}{l}\text { Average No. of } \\
\text { Dependants }\end{array}$ & 0.81 persons & 0.72 persons & 0.80 persons & 0.78 persons \\
\hline \multicolumn{5}{|l|}{$\begin{array}{l}\text { Definition } 2 \text { of } \\
\text { Informality }\end{array}$} \\
\hline $\begin{array}{l}\text { Share of Total } \\
\text { Employment }\end{array}$ & $41.47 \%$ & $45.22 \%$ & $58.63 \%$ & $54.78 \%$ \\
\hline $\begin{array}{l}\text { Share of Permanent } \\
\text { Workers }\end{array}$ & $86.6 \%$ & $84.95 \%$ & $81.27 \%$ & $79.24 \%$ \\
\hline Share of Men & $70.53 \%$ & $66.8 \%$ & $68.24 \%$ & $65.75 \%$ \\
\hline $\begin{array}{l}\text { Share of Married } \\
\text { Workers }\end{array}$ & $69.71 \%$ & $72.43 \%$ & $68.39 \%$ & $73.09 \%$ \\
\hline Average Education & 8.93 years & 9.79 years & 6.29 years & 6.95 years \\
\hline Average Age & 34.7 years & 35.02 years & 36.57 years & 37.17 years \\
\hline $\begin{array}{l}\text { Average No. of } \\
\text { Dependants }\end{array}$ & 0.84 persons & 0.77 persons & 0.78 persons & 0.73 persons \\
\hline
\end{tabular}

Notes: the table reports proportions and means of the variables in the formal and informal sectors before and after the reform using two alternative definitions of informality. The proportions and means using the first definition are presented in the top panel, while those using the second definition are presented in the bottom panel. Under definition 1, workers are defined as those whose employers pay social security taxes and informal workers are those whose employer does not pay social security contributions. Under definition 2, formal workers are defined as wage-earners employed by firms with more than 10 employees and informal workers are wage-earners employed by firms with less than 10 employees, family workers, domestic workers, and self-employed workers. In Colombia, family workers, self-employed, and workers employed by firms with less than 5 employees are completely exempt from severance pay legislation, while domestic workers and workers employed by firms with little capital are subject to half the severance payments of workers completely covered by the legislation. 
Table 4: Sample Differences-in-Differences Estimates of the Effect of the Reform on Average Tenure

\begin{tabular}{lcc}
\hline \hline & Formal & Informal \\
\hline \multirow{2}{*}{ Post-reform } & 5.3130 & 4.5376 \\
Pre-reform & $(0.0461)$ & $(0.0496)$ \\
& 5.6002 & 4.5197 \\
& $(0.0632)$ & $(0.0588)$ \\
\hline Differences & $-0.2872^{*}$ & -0.0176 \\
& $(0.0782)$ & $(0.0769)$ \\
Differences-in-Differences & & $-0.3051^{* *}$ \\
& & $(0.1098)$ \\
\end{tabular}

Table 5: Sample Differences-in-Differences Estimates of the Effect of the Reform on Average Tenure, by Gender

\begin{tabular}{lcc|cc}
\hline \hline & \multicolumn{2}{c}{ Men } & \multicolumn{2}{c}{ Women } \\
& Formal & Informal & Formal & Informal \\
\hline \multirow{2}{*}{ Post-reform } & & & & \\
& 5.57424 & 4.9987 & 4.5173 & 3.5772 \\
Pre-reform & $(0.0610)$ & $(0.0636)$ & $(0.0659)$ & $(0.0749)$ \\
& 6.1141 & 5.0270 & 4.4730 & 3.3577 \\
& $(0.0812)$ & $(0.0753)$ & $(0.0914)$ & $(0.0842)$ \\
\hline Differences & $-0.3717^{*}$ & -0.0283 & 0.0443 & $0.2194^{* *}$ \\
& $(0.1016)$ & $(0.0986)$ & $(0.1127)$ & $(0.1127)$ \\
Differences-in-Differences & $-0.3434^{*}$ & $(0.1416)$ & -0.1751 & $(0.1594)$ \\
\hline \hline
\end{tabular}


Table 6: Sample Differences-in-Differences Estimates of the Effect of the Reform on Average Tenure, by Age Group

\begin{tabular}{|c|c|c|c|c|c|c|}
\hline & \multicolumn{2}{|c|}{ Age $<24$ years } & \multicolumn{2}{|c|}{ 24- 55 years } & \multicolumn{2}{|c|}{ Age $>55$ years } \\
\hline & Formal & Informal & Formal & Informal & Formal & Informal \\
\hline Post-reform & $\begin{array}{c}1.6480 \\
(0.0331)\end{array}$ & $\begin{array}{c}1.4058 \\
(0.03030)\end{array}$ & $\begin{array}{c}5.3971 \\
(0.0821)\end{array}$ & $\begin{array}{c}4.5180 \\
(0.0525)\end{array}$ & $\begin{array}{l}11.2889 \\
(0.2860)\end{array}$ & $\begin{array}{l}10.1111 \\
(0.2523)\end{array}$ \\
\hline Pre-reform & $\begin{array}{c}1.6107 \\
(0.0394)\end{array}$ & $\begin{array}{c}1.3709 \\
(0.0309)\end{array}$ & $\begin{array}{c}5.7419 \\
(0.0663)\end{array}$ & $\begin{array}{c}4.5280 \\
(0.0615)\end{array}$ & $\begin{array}{l}12.3513 \\
(0.3589)\end{array}$ & $\begin{array}{c}10.7321 \\
(0.3008)\end{array}$ \\
\hline Differences & $\begin{array}{c}0.0372 \\
(0.0515)\end{array}$ & $\begin{array}{c}0.0349 \\
(0.0433)\end{array}$ & $\begin{array}{l}-0.3448^{*} \\
(0.0821)\end{array}$ & $\begin{array}{l}-0.0100 \\
(0.0808)\end{array}$ & $\begin{array}{l}-1.0624^{*} \\
(0.4589)\end{array}$ & $\begin{array}{l}-0.6209^{\dagger} \\
(0.3926)\end{array}$ \\
\hline Diff's-in-diff's & 0.0023 & $(0.0684)$ & $-0.3348^{*}$ & $(0.1156)$ & -0.4414 & $(0.2111)$ \\
\hline
\end{tabular}


Table 7: Sample Differences-in-Differences Estimates of the Effect of the Reform on Average Tenure, by Education Group

\begin{tabular}{|c|c|c|c|c|c|c|}
\hline & \multicolumn{2}{|c|}{ Primary Education } & \multicolumn{2}{|c|}{ Secondary Education } & \multicolumn{2}{|c|}{ High School } \\
\hline & Formal & Informal & Formal & Informal & Formal & Informal \\
\hline $\begin{array}{l}\text { Post-reform } \\
\text { Pre-reform }\end{array}$ & $\begin{array}{c}6.0542 \\
(0.1115) \\
6.6346 \\
(0.1316)\end{array}$ & $\begin{array}{c}5.1540 \\
(0.0816) \\
5.0796 \\
(0.0862)\end{array}$ & $\begin{array}{c}4.9525 \\
(0.0911) \\
4.8250 \\
(0.1105)\end{array}$ & $\begin{array}{c}3.8160 \\
(0.0745) \\
3.6165 \\
(0.0963)\end{array}$ & $\begin{array}{c}4.7533 \\
(0.0785) \\
4.9365 \\
(0.1222)\end{array}$ & $\begin{array}{c}3.9912 \\
(0.1046) \\
4.0059 \\
(0.1451)\end{array}$ \\
\hline Differences & $\begin{array}{l}-0.5803^{*} \\
(0.1724)\end{array}$ & $\begin{array}{c}0.0744 \\
(0.1187)\end{array}$ & $\begin{array}{c}0.1275 \\
(0.1432)\end{array}$ & $\begin{array}{l}0.1996^{* *} \\
(0.1218)\end{array}$ & $\begin{array}{l}-0.1832^{\dagger} \\
(0.1453)\end{array}$ & $\begin{array}{c}-0.0147 \\
(0.1788)\end{array}$ \\
\hline Diff's-in-diff's & $-0.6547^{*}$ & $(0.2111)$ & -0.0720 & $(0.1867)$ & -0.1685 & $(0.2380)$ \\
\hline
\end{tabular}

\begin{tabular}{|c|c|c|c|c|}
\hline \multirow[b]{2}{*}{ Post-reform } & \multicolumn{2}{|c|}{ University Education } & \multicolumn{2}{|c|}{$\begin{array}{c}\text { University Degree } \\
\text { or more }\end{array}$} \\
\hline & $\begin{array}{c}4.6618 \\
(0.1242)\end{array}$ & $\begin{array}{c}3.4520 \\
(0.1714)\end{array}$ & $\begin{array}{c}6.2258 \\
(0.1208)\end{array}$ & $\begin{array}{r}5.2305 \\
(0.2575)\end{array}$ \\
\hline Pre-reform & $\begin{array}{c}5.0506 \\
(0.1771)\end{array}$ & $\begin{array}{c}3.6039 \\
(0.2505)\end{array}$ & $\begin{array}{c}6.3984 \\
(0.1871)\end{array}$ & $\begin{array}{c}4.9899 \\
(0.3093)\end{array}$ \\
\hline Differences & $\begin{array}{l}-0.3888^{* *} \\
(0.2163)\end{array}$ & $\begin{array}{l}-0.1519 \\
(0.3035)\end{array}$ & $\begin{array}{c}-0.1726 \\
(0.2227)\end{array}$ & $\begin{array}{c}0.2407 \\
(0.4024)\end{array}$ \\
\hline Diff's-in-diff's & -0.2368 & $(0.4018)$ & -0.4133 & $(0.4923)$ \\
\hline
\end{tabular}


Table 8: Sample Differences-in-Differences Estimates of the Effect of the Reform on Average Tenure, by Industry

\begin{tabular}{|c|c|c|c|c|c|c|}
\hline & \multicolumn{2}{|c|}{ Agriculture } & \multicolumn{2}{|c|}{ Mining } & \multicolumn{2}{|c|}{ Manufacturing } \\
\hline & Formal & Informal & Formal & Informal & Formal & Informal \\
\hline Post-reform & $\begin{array}{c}5.6232 \\
(0.3975)\end{array}$ & $\begin{array}{c}5.0688 \\
(0.4503)\end{array}$ & $\begin{array}{c}5.8725 \\
(0.4731)\end{array}$ & $\begin{array}{c}4.1875 \\
(0.8474)\end{array}$ & $\begin{array}{c}5.3031 \\
(0.0915)\end{array}$ & $\begin{array}{c}4.2360 \\
(0.1128)\end{array}$ \\
\hline Pre-reform & $\begin{array}{c}5.724 \\
(0.6194)\end{array}$ & $\begin{array}{c}6.0402 \\
(0.4503)\end{array}$ & $\begin{array}{c}4.4010 \\
(0.5431)\end{array}$ & $\begin{array}{c}3.4091 \\
(0.7922)\end{array}$ & $\begin{array}{c}5.0920 \\
(0.1164)\end{array}$ & $\begin{array}{c}4.3843 \\
(0.1438)\end{array}$ \\
\hline Differences & $\begin{array}{l}-0.1008 \\
(0.7359)\end{array}$ & $\begin{array}{l}-0.9714 \\
(0.6947)\end{array}$ & $\begin{array}{l}1.4716^{* *} \\
(0.7245)\end{array}$ & $\begin{array}{c}0.7784 \\
(1.1601)\end{array}$ & $\begin{array}{c}0.2112^{\dagger} \\
(0.1481)\end{array}$ & $\begin{array}{c}-0.1483 \\
(0.1827)\end{array}$ \\
\hline \multirow[t]{2}{*}{ Diff's-in-diff's } & 0.8706 & (1.0964) & 0.6931 & $(1.3608)$ & 0.3595 & $(0.2341)$ \\
\hline & \multicolumn{2}{|c|}{ Utilities } & \multicolumn{2}{|c|}{ Construction } & \multicolumn{2}{|c|}{ Commerce } \\
\hline Post-reform & $\begin{array}{c}6.8926 \\
(0.3778)\end{array}$ & - & $\begin{array}{c}4.0121 \\
(0.1859)\end{array}$ & $\begin{array}{c}4.2889 \\
(0.1729)\end{array}$ & $\begin{array}{c}4.5763 \\
(0.0823)\end{array}$ & $\begin{array}{c}4.9136 \\
(0.0862)\end{array}$ \\
\hline Pre-reform & $\begin{array}{c}7.9114 \\
(0.4736)\end{array}$ & - & $\begin{array}{c}4.0532 \\
(0.2558)\end{array}$ & $\begin{array}{c}3.4439 \\
(0.1904)\end{array}$ & $\begin{array}{c}4.6654 \\
(0.1217)\end{array}$ & $\begin{array}{c}4.9855 \\
(0.1001)\end{array}$ \\
\hline Differences & $\begin{array}{l}-1.0188^{*} \\
(0.6059)\end{array}$ & - & $\begin{array}{c}0.0411 \\
(0.3163)\end{array}$ & $\begin{array}{c}0.8449^{*} \\
(0.2572)\end{array}$ & $\begin{array}{l}-0.0892 \\
(0.1469)\end{array}$ & $\begin{array}{c}-0.0719 \\
(0.1321)\end{array}$ \\
\hline \multirow[t]{2}{*}{ Diff's-in-diff's } & - & & -0.8861 & $(0.4382)$ & -0.0173 & $(0.2046)$ \\
\hline & \multicolumn{2}{|c|}{ Transportation } & \multicolumn{2}{|c|}{ Financial Services } & \multicolumn{2}{|c|}{ Services } \\
\hline Post-reform & $\begin{array}{c}5.22 \\
(0.1766)\end{array}$ & $\begin{array}{c}4.5496 \\
(0.1564)\end{array}$ & $\begin{array}{c}4.8835 \\
(0.1364)\end{array}$ & $\begin{array}{c}5.1026 \\
(0.2744)\end{array}$ & $\begin{array}{c}6.2118 \\
(0.0992)\end{array}$ & $\begin{array}{c}4.2454 \\
(0.0985)\end{array}$ \\
\hline Pre-reform & $\begin{array}{c}6.1895 \\
(0.2455)\end{array}$ & $\begin{array}{c}4.9789 \\
(0.2144)\end{array}$ & $\begin{array}{c}5.6848 \\
(0.2072)\end{array}$ & $\begin{array}{c}5.0121 \\
(0.3692)\end{array}$ & $\begin{array}{c}6.8428 \\
(0.1332)\end{array}$ & $\begin{array}{c}4.0234 \\
(0.1053)\end{array}$ \\
\hline Differences & $\begin{array}{l}-0.9695^{*} \\
(0.3025)\end{array}$ & $\begin{array}{l}0.4292^{* *} \\
(0.2654)\end{array}$ & $\begin{array}{l}-0.8013^{*} \\
(0.2480)\end{array}$ & $\begin{array}{c}0.0905 \\
(1.2636)\end{array}$ & $\begin{array}{l}-0.6310^{*} \\
(0.1661)\end{array}$ & $\begin{array}{c}0.2220^{\dagger} \\
(0.1442)\end{array}$ \\
\hline Diff's-in-diff's & $-0.5403^{\dagger}$ & $(0.4009)$ & $-0.8919^{* *}$ & $(0.4961)$ & $-0.8530^{*}$ & $(0.2189)$ \\
\hline
\end{tabular}


Table 9: Sample Differences-in-Differences Estimates of the Effect of the Reform on Average Tenure, by Firm Size

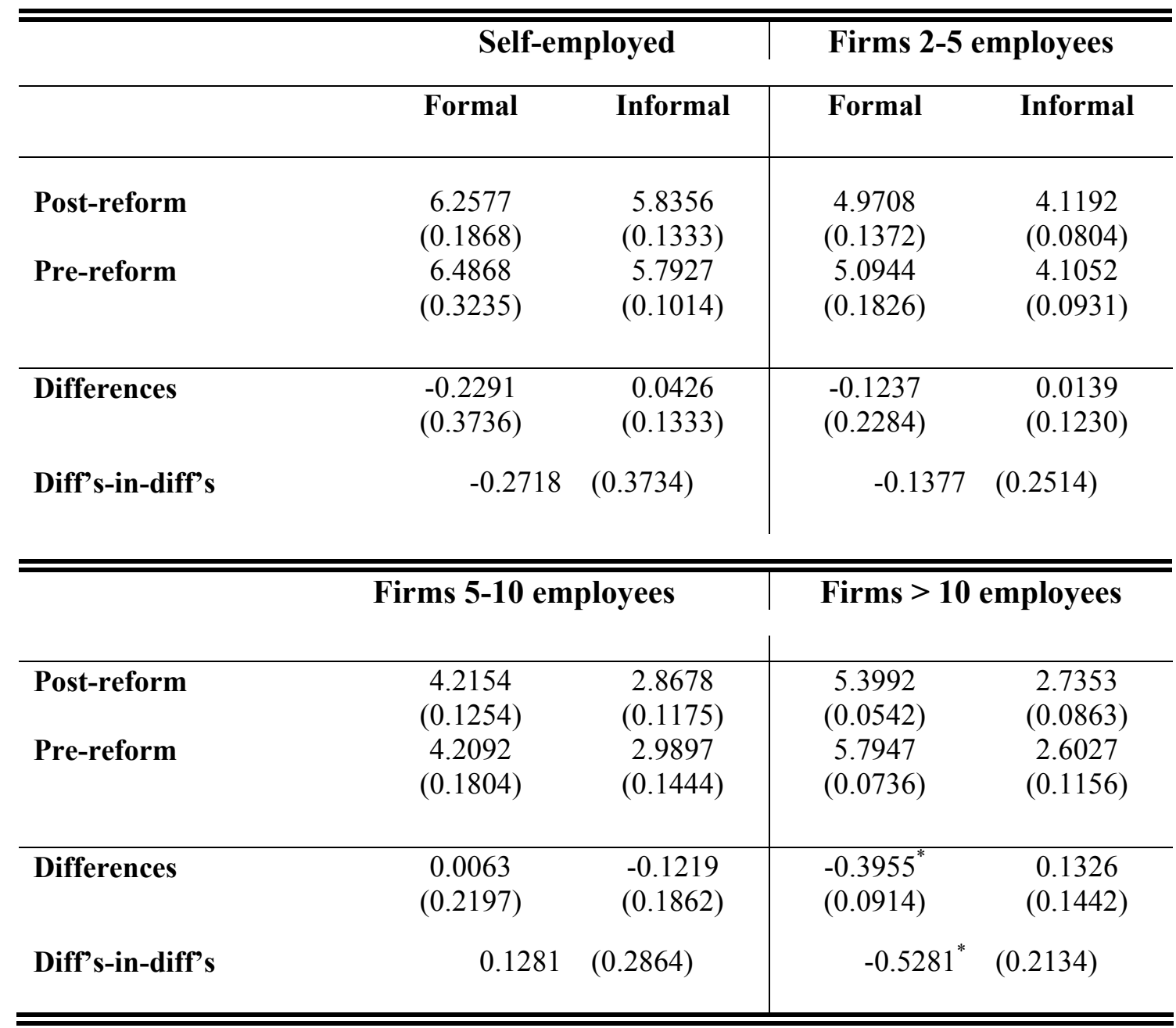


Table 10: Sample Differences-in-Differences Estimates of the Effect of the Reform on Average Unemployment Duration

\begin{tabular}{lcc}
\hline \hline & Formal & Informal \\
\hline \multirow{2}{*}{ Post-reform } & 7.5985 & 9.7731 \\
\multirow{2}{*}{ Pre-reform } & $(0.1187)$ & $(0.1489)$ \\
& 7.3328 & 8.7297 \\
& $(0.1489)$ & $(0.1630)$ \\
\hline Differences & $0.2657^{\dagger}$ & $1.0434^{*}$ \\
& $(0.1904)$ & $(0.2208)$ \\
Differences-in-Differences & & $-0.7777^{*}$ \\
& & $(0.2929)$ \\
\end{tabular}

Table 11: Sample Differences-in-Differences Estimates of the Effect of the Reform on Average Unemployment Duration, by Gender

\begin{tabular}{lcc|cc}
\hline \hline & \multicolumn{2}{c}{ Men } & \multicolumn{2}{c}{ Women } \\
& Formal & Informal & Formal & Informal \\
\hline \multirow{2}{*}{ Post-reform } & 6.6402 & 7.3753 & 9.3743 & 14.7665 \\
& $(0.1284)$ & $(0.1420)$ & $(0.2394)$ & $(0.3413)$ \\
Pre-reform & 6.3455 & 6.9092 & 9.4983 & 12.8988 \\
& $(0.1536)$ & $(0.1569)$ & $(0.3321)$ & $(0.3894)$ \\
\hline Differences & $0.2947^{* *}$ & $0.4660^{*}$ & -0.1240 & $1.8678^{*}$ \\
& $(0.2002)$ & $(0.2116)$ & $(0.4094)$ & $(0.5178)$ \\
Differences-in-Differences & -0.1713 & $(0.2925)$ & $-1.9918^{*}$ & $(0.6592)$ \\
& & & & \\
\hline \hline
\end{tabular}


Table 12: Sample Differences-in-Differences Estimates of the Effect of the Reform on Average Unemployment Duration, by Age Group

\begin{tabular}{lcc|cc|cc}
\hline \hline & \multicolumn{2}{c|}{ Age $<24$ years } & \multicolumn{2}{c|}{ 24- 55 years } & \multicolumn{2}{c}{ Age $>55$ years } \\
\hline & Formal & Informal & Formal & Informal & Formal & Informal \\
& & & & & & \\
\hline \multirow{2}{*}{ Post-reform } & 5.0951 & 5.7650 & 7.6482 & 10.0925 & 11.7779 & 14.7266 \\
& $(0.1924)$ & $(0.1940)$ & $(0.1328)$ & $(0.1813)$ & $(0.6590)$ & $(0.6043)$ \\
Pre-reform & 5.3906 & 5.2083 & 7.5569 & 9.2324 & 9.0156 & 12.8679 \\
& $(0.2454)$ & $(0.1823)$ & $(0.1729)$ & $(0.2077)$ & $(0.7171)$ & $(0.6642)$ \\
\hline Differences & -0.2956 & $0.5567^{*}$ & 0.0914 & $0.8601^{*}$ & $2.7623^{*}$ & $1.8587^{* *}$ \\
& $(0.3118)$ & $(0.2662)$ & $(0.2180)$ & $(0.2757)$ & $(0.9739)$ & $(0.8979)$ \\
Diff's-in-diff's & $-0.8523^{* *}$ & $(0.4184)$ & $-0.7688^{*}$ & $(0.3481)$ & 0.9037 & $(0.1396)$ \\
\hline \hline
\end{tabular}


Table 13: Sample Differences-in-Differences Estimates of the Effect of the Reform on Average Unemployment Duration, by Education Group

\begin{tabular}{lcc|cc|cc}
\hline \hline & \multicolumn{2}{c|}{ Primary Education } & \multicolumn{2}{c}{ Secondary Education } & \multicolumn{2}{c}{ High School } \\
\hline \multirow{2}{*}{ Formal } & Informal & Formal & Informal & Formal & Informal \\
& & & & & \\
Pre-reform & 8.8191 & 9.4874 & 7.8214 & 9.6863 & 7.5593 & 10.8365 \\
& $(0.2843)$ & $(0.2115)$ & $(0.2306)$ & $(0.2738)$ & $(0.2248)$ & $(0.4081)$ \\
& 7.4296 & 8.4493 & 8.1881 & 8.5266 & 7.4414 & 11.1706 \\
Differences & $(0.2739)$ & $(0,2166)$ & $(0.2948)$ & $(0.2956)$ & $(0.3164)$ & $(0.5824)$ \\
& $1.3894^{*}$ & $1.0381^{*}$ & -0.3666 & $1.1597^{* *}$ & 0.1179 & -0.3341 \\
Diff's-in-diff's & $(0.3948)$ & $(0.3027)$ & $(0.3742)$ & $(0.4029)$ & $(0.3881)$ & $(0.7111)$ \\
& 0.3513 & $(0.5224)$ & $-0.5263^{*}$ & $(0.5560)$ & 0.4520 & $(0.7431)$ \\
\hline \hline
\end{tabular}

\begin{tabular}{c|c} 
University Education & $\begin{array}{c}\text { University Degree } \\
\text { or more }\end{array}$
\end{tabular}

\begin{tabular}{lcc|cc|}
\hline Post-reform & 6.7676 & 10.9950 & 6.0907 & 8.9383 \\
& $(0.3448)$ & $(0.8242)$ & $(0.2727)$ & $(0.6899)$ \\
Pre-reform & 6.9614 & 8.3146 & 5.3086 & 7.8942 \\
& $(0.4944)$ & $(0.8936)$ & $(0.3918)$ & $(0.9386)$ \\
\hline Differences & -0.1938 & $2.6804^{*}$ & $0.7822^{* *}$ & 1.0441 \\
& $(0.6027)$ & $(1.2157)$ & $(0.4773)$ & $(1.1648)$ \\
Diff's-in-diff's & $-2.8742^{*}$ & $(1.2379)$ & -0.2619 & $(1.1239)$ \\
\hline \hline
\end{tabular}


Table 14: Sample Differences-in-Differences Estimates of the Effect of the Reform on Average Unemployment Duration, by Industry

\begin{tabular}{|c|c|c|c|c|c|c|}
\hline & \multicolumn{2}{|c|}{ Agriculture } & \multicolumn{2}{|c|}{ Mining } & \multicolumn{2}{|c|}{ Manufacturing } \\
\hline & Formal & Informal & Formal & Informal & Formal & Informal \\
\hline Post-reform & $\begin{array}{c}6.5332 \\
(0.9948)\end{array}$ & $\begin{array}{c}6.5428 \\
(0.8265)\end{array}$ & $\begin{array}{c}6.0294 \\
(1.1816)\end{array}$ & $\begin{array}{c}6.2292 \\
(2.2612)\end{array}$ & $\begin{array}{c}7.2766 \\
(0.2177)\end{array}$ & $\begin{array}{l}10.2512 \\
(0.3665)\end{array}$ \\
\hline Pre-reform & $\begin{array}{c}7.812 \\
(1.3781)\end{array}$ & $\begin{array}{c}6.3489 \\
(0.8538)\end{array}$ & $\begin{array}{c}5.9455 \\
(1.1462)\end{array}$ & $\begin{array}{c}6.5606 \\
(2.0028)\end{array}$ & $\begin{array}{c}7.4136 \\
(0.2703)\end{array}$ & $\begin{array}{c}9.9015 \\
(0.4279)\end{array}$ \\
\hline Differences & $\begin{array}{l}-1.2788 \\
(1.6995)\end{array}$ & $\begin{array}{c}0.1939 \\
(1.1883)\end{array}$ & $\begin{array}{c}0.0839 \\
(1.6462)\end{array}$ & $\begin{array}{c}-0.3314 \\
(3.0207)\end{array}$ & $\begin{array}{l}-0.1370 \\
(0.3471)\end{array}$ & $\begin{array}{c}0.3496 \\
(0.5634)\end{array}$ \\
\hline \multirow[t]{2}{*}{ Diff's-in-diff's } & -1.4728 & $(2.0497)$ & 0.4153 & $(3.2289)$ & -0.4866 & $(0.6275)$ \\
\hline & \multicolumn{2}{|c|}{ Utilities } & \multicolumn{2}{|c|}{ Construction } & \multicolumn{2}{|c|}{ Commerce } \\
\hline $\begin{array}{l}\text { Post-reform } \\
\text { Pre-reform }\end{array}$ & $\begin{array}{c}9.8 \\
(1.1168) \\
6.4314 \\
(0.8747)\end{array}$ & $\begin{array}{c}6.5 \\
(1.6065) \\
3 \\
(1.5)\end{array}$ & $\begin{array}{c}5.8669 \\
(0.4841) \\
5.4792 \\
(0.5700)\end{array}$ & $\begin{array}{c}5.3911 \\
(0.2734) \\
4.8239 \\
(0.2947)\end{array}$ & $\begin{array}{c}7.4709 \\
(0.2522) \\
7.4513 \\
(0.3427)\end{array}$ & $\begin{array}{c}11.59 \\
(0.2940) \\
10.3010 \\
(0.3118)\end{array}$ \\
\hline Differences & $\begin{array}{c}3.3686^{*} \\
(1.4186)\end{array}$ & $\begin{array}{c}3.5^{\dagger} \\
(2.1979)\end{array}$ & $\begin{array}{c}0.3878 \\
(0.7478)\end{array}$ & $\begin{array}{c}0.5671^{\dagger} \\
(0.4019)\end{array}$ & $\begin{array}{c}0.0197 \\
(0.4254)\end{array}$ & $\begin{array}{c}1.2943 \\
(0.4286)\end{array}$ \\
\hline \multirow[t]{2}{*}{ Diff's-in-diff's } & -0.1314 & $(6.2663)$ & -0.1794 & $(0.7816)$ & $-1.2746^{* *}$ & $(0.6425)$ \\
\hline & \multicolumn{2}{|c|}{ Transportation } & \multicolumn{2}{|c|}{ Financial Services } & \multicolumn{2}{|c|}{ Services } \\
\hline Post-reform & $\begin{array}{c}6.3961 \\
(0.3678)\end{array}$ & $\begin{array}{c}6.9820 \\
(0.3759)\end{array}$ & $\begin{array}{c}6.9234 \\
(0.3546)\end{array}$ & $\begin{array}{c}9.6664 \\
(0.7508)\end{array}$ & $\begin{array}{c}8.8563 \\
(0.2602)\end{array}$ & $\begin{array}{l}10.1112 \\
(0.3019)\end{array}$ \\
\hline Pre-reform & $\begin{array}{c}6.6343 \\
(0.5120)\end{array}$ & $\begin{array}{c}6.4011 \\
(0.4580)\end{array}$ & $\begin{array}{c}6.6883 \\
(0.4317)\end{array}$ & $\begin{array}{l}10.1782 \\
(1.0164)\end{array}$ & $\begin{array}{c}8.0041 \\
(0.3233)\end{array}$ & $\begin{array}{c}7.9464 \\
(0.2956)\end{array}$ \\
\hline Differences & $\begin{array}{l}-0.2381 \\
(0.6304)\end{array}$ & $\begin{array}{c}0.5809 \\
(0.5925)\end{array}$ & $\begin{array}{c}0.2351 \\
(0.5586)\end{array}$ & $\begin{array}{c}0.5119 \\
(1.2636)\end{array}$ & $\begin{array}{l}0.8522^{* *} \\
(0.4150)\end{array}$ & $\begin{array}{c}2.1648^{*} \\
(0.4226)\end{array}$ \\
\hline Diff's-in-diff's & -0.8190 & $(0.8679)$ & -0.7470 & (1.1993) & $-1.3126^{*}$ & $(0.5924)$ \\
\hline
\end{tabular}


Table 15: Sample Differences-in-Differences Estimates of the Effect of the Reform on Average Unemployment Duration, by Firm Size

\begin{tabular}{|c|c|c|c|c|}
\hline & \multicolumn{2}{|c|}{ Self-employed } & \multicolumn{2}{|c|}{ Firms 2-5 employees } \\
\hline & Formal & Informal & Formal & Informal \\
\hline Post-reform & $\begin{array}{c}9.8851 \\
(0.5317)\end{array}$ & $\begin{array}{l}12.0358 \\
(0.2641)\end{array}$ & $\begin{array}{c}8.3693 \\
(0.3914)\end{array}$ & $\begin{array}{c}8.7661 \\
(0.2359)\end{array}$ \\
\hline Pre-reform & $\begin{array}{c}8.4208 \\
(0.8966)\end{array}$ & $\begin{array}{l}10.3226 \\
(0.2876)\end{array}$ & $\begin{array}{c}7.2331 \\
(0.4802)\end{array}$ & $\begin{array}{c}8.2628 \\
(0.2618)\end{array}$ \\
\hline Differences & $\begin{array}{c}1.4642^{\dagger} \\
(1.0424)\end{array}$ & $\begin{array}{l}1.7132^{*} \\
(0.3905)\end{array}$ & $\begin{array}{l}1.1361^{* *} \\
(0.6195)\end{array}$ & $\begin{array}{c}0.5033^{\dagger} \\
(0.3524)\end{array}$ \\
\hline Diff's-in-diff's & -0.2490 & $(1.0863)$ & 0.6328 & $(0.7099)$ \\
\hline
\end{tabular}

\begin{tabular}{|c|c|c|c|c|}
\hline \multirow[b]{2}{*}{ Post-reform } & \multicolumn{2}{|c|}{ Firms 5-10 employees } & \multicolumn{2}{|c|}{ Firms $>10$ employees } \\
\hline & $\begin{array}{c}6.7852 \\
(0.3668)\end{array}$ & $\begin{array}{c}6.6247 \\
(0.3684)\end{array}$ & $\begin{array}{c}7.3144 \\
(0.1333)\end{array}$ & $\begin{array}{c}7.3804 \\
(0.2880)\end{array}$ \\
\hline Pre-reform & $\begin{array}{c}6.6018 \\
(0.4255)\end{array}$ & $\begin{array}{c}5.6375 \\
(0.3359)\end{array}$ & $\begin{array}{c}7.3701 \\
(0.1687)\end{array}$ & $\begin{array}{c}7.1446 \\
(0.3545)\end{array}$ \\
\hline Differences & $\begin{array}{c}0.1834 \\
(0.5618)\end{array}$ & $\begin{array}{c}0.9872 \\
(0.4986)\end{array}$ & $\begin{array}{l}-0.0556^{*} \\
(0.2150)\end{array}$ & $\begin{array}{c}0.2358 \\
(0.3926)\end{array}$ \\
\hline Diff's-in-diff's & -0.8038 & $(0.7486)$ & -0.2913 & $(0.5205)$ \\
\hline
\end{tabular}


Table 16: Exponential Hazard Model Estimates of Employment Duration ( $n=55,683$ )

\begin{tabular}{|c|c|c|c|c|}
\hline Variable & (1) & (2) & (3) & (4) \\
\hline Formal & $\begin{array}{l}-0.2286 \\
(0.0013)\end{array}$ & $\begin{array}{c}0.1354 \\
(0.0036)\end{array}$ & $\begin{array}{l}-0.0853 \\
(0.0027)\end{array}$ & $\begin{array}{l}-0.2409 \\
(0.0105)\end{array}$ \\
\hline Post90 & $\begin{array}{l}-0.1247 \\
(0.0011)\end{array}$ & $\begin{array}{l}-0.0508 \\
(0.0022)\end{array}$ & $\begin{array}{l}-0.0483 \\
(0.0019)\end{array}$ & $\begin{array}{c}0.0688 \\
(0.0080)\end{array}$ \\
\hline Formal $\times$ Post 90 & $\begin{array}{c}0.0617 \\
(0.0015)\end{array}$ & $\begin{array}{c}0.0673 \\
(0.0042)\end{array}$ & $\begin{array}{c}0.0279 \\
(0.0032)\end{array}$ & $\begin{array}{c}0.0284 \\
(0.0129)\end{array}$ \\
\hline Permanent & - & $\begin{array}{l}-0.3939 \\
(0.0021)\end{array}$ & - & - \\
\hline Formal $\times$ Permanent & - & $\begin{array}{l}-0.3401 \\
(0.0039)\end{array}$ & - & - \\
\hline Post90 $\times$ Permanent & - & $\begin{array}{c}0.0268 \\
(0.0026)\end{array}$ & - & - \\
\hline $\begin{array}{l}\text { Formal } \times \text { Post } 90 \times \\
\text { Permanent }\end{array}$ & - & $\begin{array}{l}-0.0062 \\
(0.0045)\end{array}$ & - & - \\
\hline $\begin{array}{l}\text { Formal } \times \text { Post } 90 \times \\
\text { Age } 25-55 \text { years }\end{array}$ & - & - & $\begin{array}{c}0.0359 \\
(0.0029)\end{array}$ & - \\
\hline $\begin{array}{l}\text { Formal } \times \text { Post } 90 \times \\
\text { Age }>55 \text { years }\end{array}$ & - & - & $\begin{array}{l}-0.0222 \\
(0.0049)\end{array}$ & - \\
\hline $\begin{array}{l}\text { Formal } \times \text { Post } 90 \times \\
\text { Secondary Educ. }\end{array}$ & - & - & $\begin{array}{c}0.0124 \\
(0.0031)\end{array}$ & - \\
\hline $\begin{array}{l}\text { Formal } \times \text { Post } 90 \times \\
\text { High-School Degr. }\end{array}$ & - & - & $\begin{array}{c}0.0538 \\
(0.0035)\end{array}$ & - \\
\hline $\begin{array}{l}\text { Formal } \times \text { Post } 90 \times \\
\text { University Educ. }\end{array}$ & - & - & $\begin{array}{c}0.0596 \\
(0.0035)\end{array}$ & - \\
\hline $\begin{array}{l}\text { Formal } \times \text { Post } 90 \times \\
\text { University Degr. }\end{array}$ & - & - & $\begin{array}{l}-0.0254 \\
(0.0054)\end{array}$ & - \\
\hline $\begin{array}{l}\text { Formal } \times \text { Post } 90 \times \\
\text { Mining }\end{array}$ & - & - & - & $\begin{array}{l}-0.4799 \\
(0.0281)\end{array}$ \\
\hline $\begin{array}{l}\text { Formal } \times \text { Post } 90 \times \\
\text { Manufacturing }\end{array}$ & - & - & - & $\begin{array}{l}-0.0321 \\
(0.0133)\end{array}$ \\
\hline $\begin{array}{l}\text { Formal } \times \text { Post } 90 \times \\
\text { Utilities }\end{array}$ & - & - & - & $\begin{array}{c}1.9788 \\
(0.0661)\end{array}$ \\
\hline $\begin{array}{l}\text { Formal } \times \text { Post } 90 \times \\
\text { Construction }\end{array}$ & - & - & - & $\begin{array}{c}0.0867 \\
(0.0143)\end{array}$ \\
\hline $\begin{array}{l}\text { Formal } \times \text { Post } 90 \times \\
\text { Commerce }\end{array}$ & - & - & - & $\begin{array}{l}-0.0033 \\
(0.0133)\end{array}$ \\
\hline $\begin{array}{l}\text { Formal } \times \text { Post } 90 \times \\
\text { Transportation }\end{array}$ & - & - & - & $\begin{array}{c}0.1178 \\
(0.0141)\end{array}$ \\
\hline $\begin{array}{l}\text { Formal } \times \text { Post } 90 \times \\
\text { Financial Services }\end{array}$ & - & - & - & $\begin{array}{c}0.1339 \\
(0.0144)\end{array}$ \\
\hline $\begin{array}{l}\text { Formal } \times \text { Post } 90 \times \\
\text { Services }\end{array}$ & - & - & - & $\begin{array}{c}0.0367 \\
(0.0133) \\
\end{array}$ \\
\hline Log-likelihood & $-12,256,412$ & $-12,131,391$ & $-12,157,990$ & $-12,240,447$ \\
\hline
\end{tabular}

Notes: the table reports changes in the employment hazard estimate with exponential hazard models. The models include: three age dummies, five education dummies, dummies for sex and marital status, number of dependents, nine industry dummies, and six city dummies. Asymptotic standard errors are in parenthesis. 
Table 17: Exponential hazard models of unemployment duration $(n=\mathbf{5 5 , 6 8 3})$

\begin{tabular}{|c|c|c|c|c|}
\hline Variable & (1) & (2) & (3) & (4) \\
\hline \multirow[t]{2}{*}{ Formal } & 0.0575 & -0.0070 & -0.1752 & -0.3308 \\
\hline & $(0.0016)$ & $(0.0036)$ & $(0.0036)$ & $(0.0107)$ \\
\hline \multirow{2}{*}{ Post90 } & -0.0450 & -0.0255 & -0.1202 & 0.0563 \\
\hline & $(0.0011)$ & $(0.0023)$ & $(0.0028)$ & $(0.0081)$ \\
\hline \multirow[t]{2}{*}{ Formal $\times$ Post 90} & 0.0575 & 0.0400 & 0.0827 & 0.3271 \\
\hline & $(0.0016)$ & $(0.0042)$ & $(0.0045)$ & $(0.0131)$ \\
\hline \multirow[t]{2}{*}{ Permanent } & - & 0.2676 & - & - \\
\hline & & $(0.0022)$ & & \\
\hline \multirow[t]{2}{*}{ Formal $\times$ Permanent } & - & 0.1335 & - & - \\
\hline & & $(0.0039)$ & & \\
\hline \multirow[t]{2}{*}{ Post90 $\times$ Permanent } & - & -0.0092 & - & - \\
\hline & & $(0.0026)$ & & \\
\hline Formal $\times$ Post $90 \times$ & - & 0.0208 & - & - \\
\hline Permanent & & $(0.0046)$ & & \\
\hline Formal $\times$ Post $90 \times$ & - & - & -0.1908 & - \\
\hline Age $25-55$ years & & & $(0.0041)$ & \\
\hline Formal $\times$ Post $90 \times$ & - & - & -0.3479 & - \\
\hline Age $>55$ years & & & $(0.0066)$ & \\
\hline Formal $\times$ Post $90 \times$ & - & - & 0.1468 & - \\
\hline Secondary Educ. & & & $(0.0041)$ & \\
\hline Formal $\times$ Post $90 \times$ & - & - & 0.1195 & - \\
\hline High School Degr. & & & $(0.0047)$ & \\
\hline Formal $\times$ Post $90 \times$ & - & - & 0.4229 & - \\
\hline University Educ. & & & $(0.0072)$ & \\
\hline Formal $\times$ Post $90 \times$ & - & - & 0.2184 & - \\
\hline University Degr. & & & $(0.0066)$ & \\
\hline Formal $\times$ Post $90 \times$ & - & - & - & 0.0493 \\
\hline Mining & & & & $(0.0282)$ \\
\hline Formal $\times$ Post $90 \times$ & - & - & - & -0.2995 \\
\hline Manufacturing & & & & $(0.0135)$ \\
\hline Formal $\times$ Post $90 \times$ & - & - & - & -0.0830 \\
\hline Utilities & & & & $(0.0661)$ \\
\hline Formal $\times$ Post $90 \times$ & - & - & - & -0.3426 \\
\hline Construction & & & & $(0.0145)$ \\
\hline Formal $\times$ Post $90 \times$ & - & - & - & -0.2617 \\
\hline Commerce & & & & $(0.0134)$ \\
\hline Formal $\times$ Post $90 \times$ & - & - & - & -0.2872 \\
\hline Transportation & & & & $(0.0142)$ \\
\hline Formal $\times$ Post $90 \times$ & - & - & - & -0.3947 \\
\hline Financial Services & & & & $(0.0146)$ \\
\hline Formal $\times$ Post $90 \times$ & - & - & - & -0.2237 \\
\hline Services & & & & $(0.0134)$ \\
\hline Log-likelihood & $-17,671,211$ & $-17,613,645$ & $-17,639,878$ & $-17,643,799$ \\
\hline
\end{tabular}

Notes: the table reports changes in the unemployment hazard estimated with exponential hazard models. The models include: three age dummies, five education dummies, dummies for sex and marital status, number of dependents, nine industry dummies, and six city dummies. Asymptotic standard errors are in parenthesis. 
Figure 1: Kaplan-Meier Employment Survival Estimates, by Period and Coverage

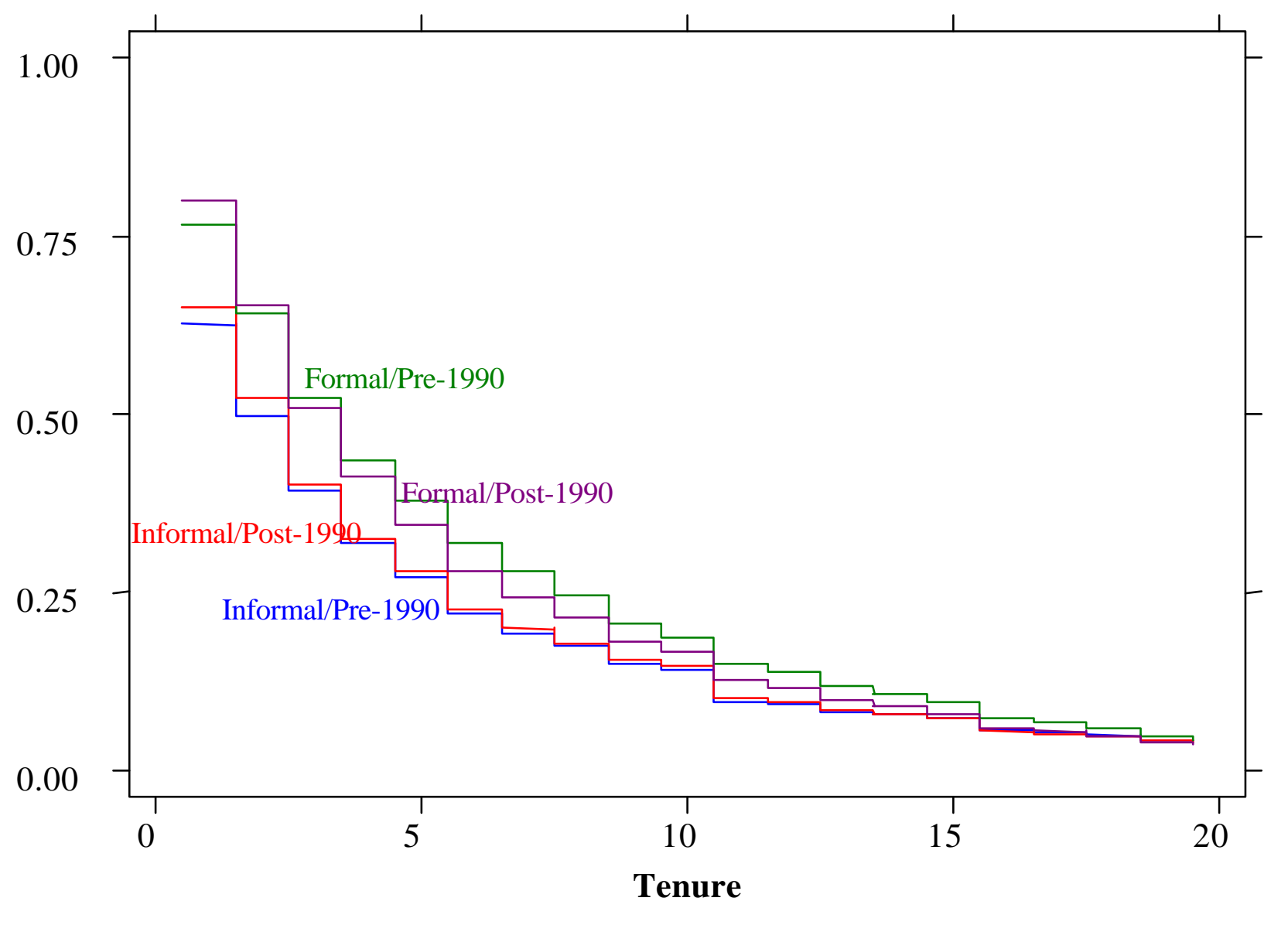




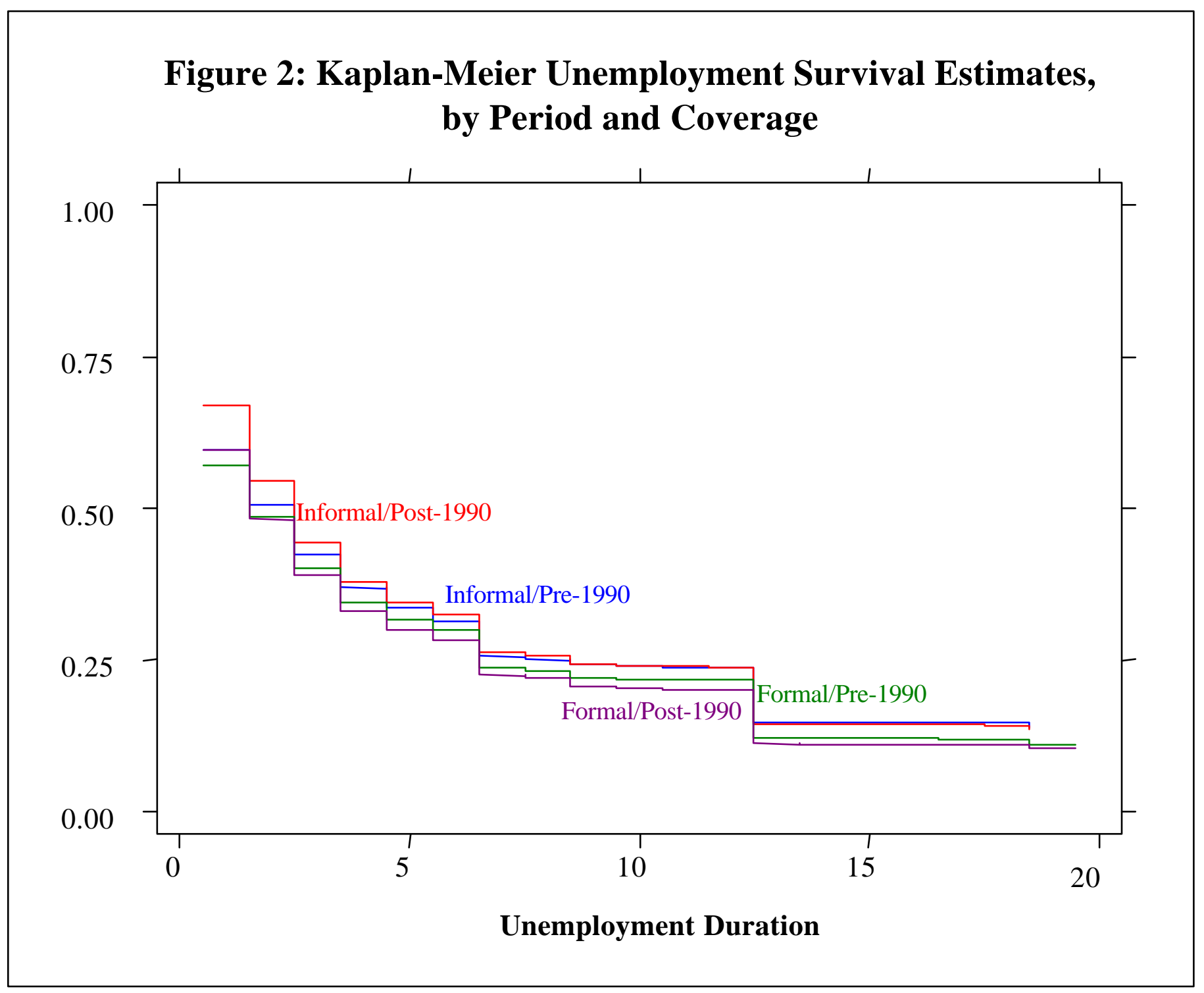

